US Army Corps

of Engineers ${ }_{\circledast}$

Engineer Research and

Development Center

Geotechnical Inspection and Technical Review of Santa Margarita River Marine Corps Air Station Levee, U.S. Marine Corps, Camp Pendleton, CA, 19-20 November 2019

Lucas A. Walshire and Joseph B. Dunbar

August 2021

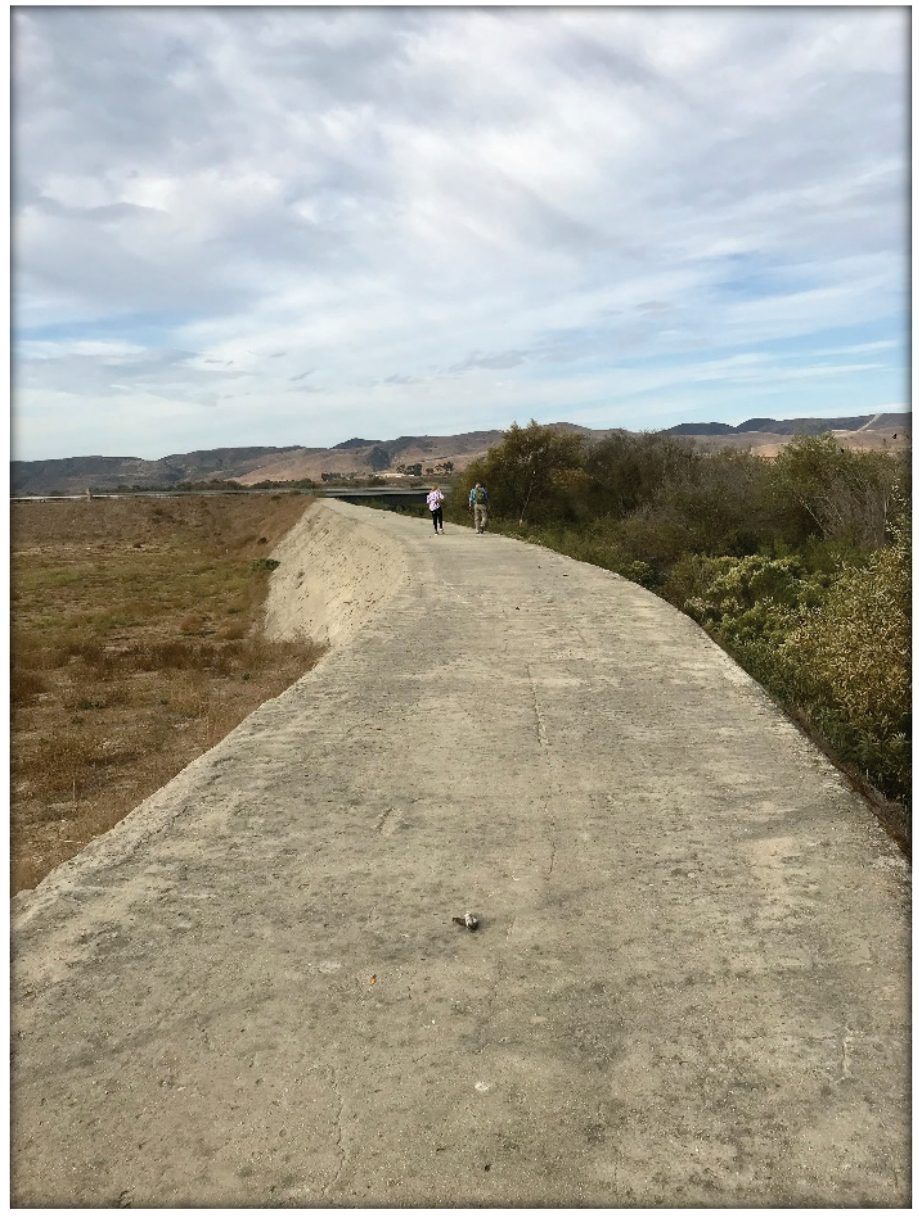


The U.S. Army Engineer Research and Development Center (ERDC) solves the nation's toughest engineering and environmental challenges. ERDC develops innovative solutions in civil and military engineering, geospatial sciences, water resources, and environmental sciences for the Army, the Department of Defense, civilian agencies, and our nation's public good. Find out more at www.erdc.usace.army.mil.

To search for other technical reports published by ERDC, visit the ERDC online library at https://erdclibrary.on.worldcat.org/discovery. 


\section{Geotechnical Inspection and Technical Review of Santa Margarita River Marine Corps Air Station Levee, U.S. Marine Corps, Camp Pendleton, CA, 19-20 November 2019}

Lucas A. Walshire and Joseph B. Dunbar

Geotechnical and Structures Laboratory

U.S. Army Engineer Research and Development Center

3909 Halls Ferry Road

Vicksburg, MS 39180-6199

Final report

Approved for public release; distribution is unlimited.

Prepared for Marine Corps Air Station

Camp Pendleton, CA 92055

Under Project DD1144-2019-GSL-604, Independent Technical Review of the Santa Margarita Levee Rehabilitation Project, MIPR M0220821MPFE001 


\section{Abstract}

This report describes activities performed, results obtained, and conclusions made from an independent technical review of past levee inspections and the proposed remediation plan for the Santa Margarita Levee that surrounds the U.S. Marine Corps Air Station (MCAS) Camp Pendleton. In support of the technical review, ERDC personnel performed a supplemental levee inspection on 19 and 20 November 2019 with MCAS personnel. Previous levee inspections had rated the levee system as Unacceptable due to unwanted vegetation encroaching on the levee rightof-way, which prevents full inspection during flooding. Concerns were raised by the U.S. Fish and Wildlife (USFW) about environmental impacts of the proposed remediation measures and the necessity of such actions. USFW personnel requested an engineering review from an independent party, and ERDC was tasked with performing the independent technical review. The following special report describes the tasks performed and results obtained from the independent technical review.

DISCLAIMER: The contents of this report are not to be used for advertising, publication, or promotional purposes. Citation of trade names does not constitute an official endorsement or approval of the use of such commercial products. All product names and trademarks cited are the property of their respective owners. The findings of this report are not to be construed as an official Department of the Army position unless so designated by other authorized documents. 


\section{Contents}

Abstract.............................................................................................................................. ii

Figures......................................................................................................................................

Preface ..................................................................................................................................... vi

1 Introduction ........................................................................................................... 1

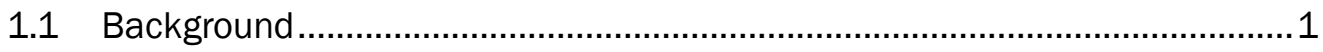

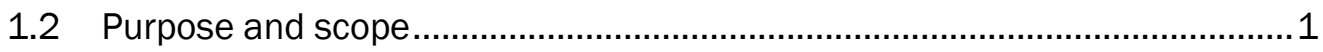

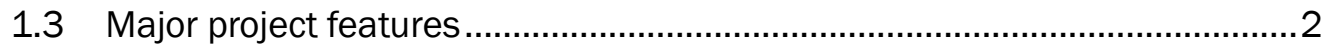

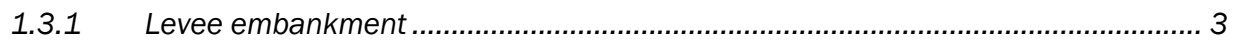

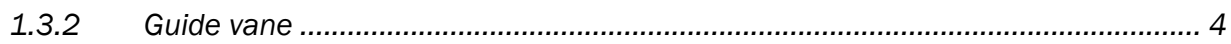

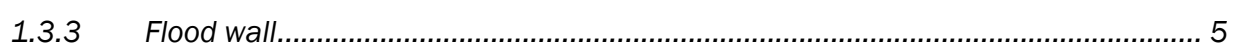

1.3.4 Hydraulic design......................................................................................... 5

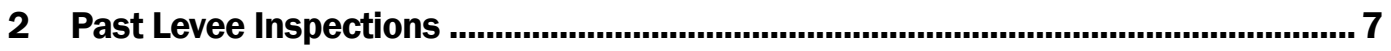

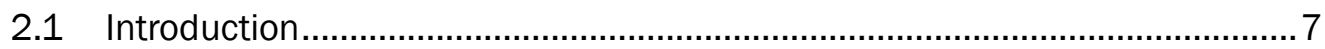

2.22012 major findings of inspection and rating (Terracon and GEI

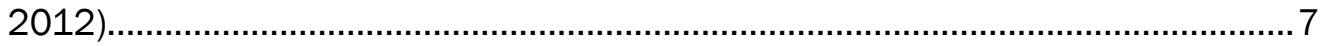

2.3 2017 inspection major findings and rating (USACE 2017) .........................8

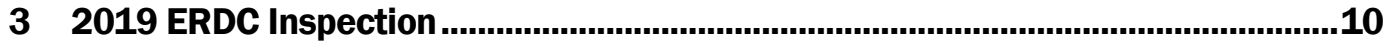

3.1 Introduction ..................................................................................... 10

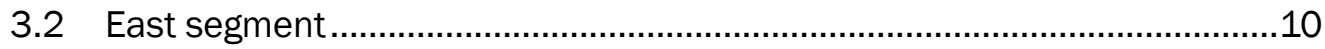

3.2.1 East levee segment key findings.................................................................... 14

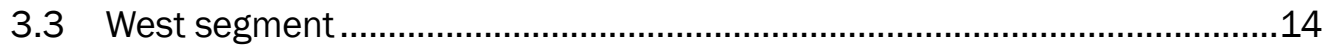

3.3.1 West levee segment key findings................................................................... 15

3.4 Floodwall segment.......................................................................

3.4.1 Floodwall segment key findings .................................................................... 18

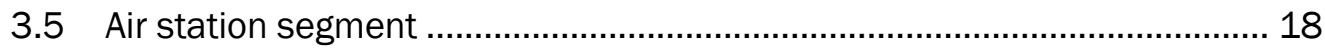

3.5.1 Air station levee segment key findings .......................................................... 20

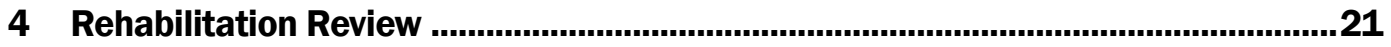

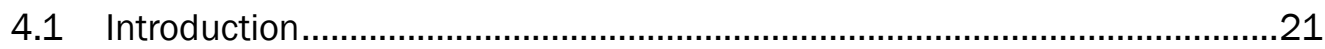

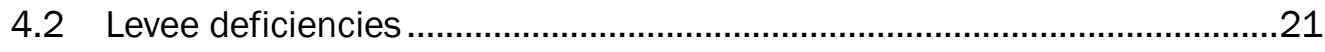

4.2.1 East levee embankment .................................................................................. 21

4.2.2 Air station levee segment ................................................................................. 22

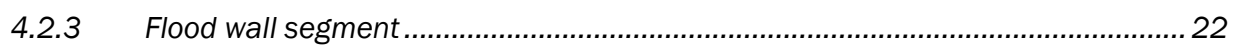

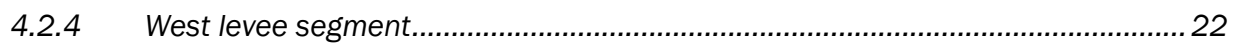

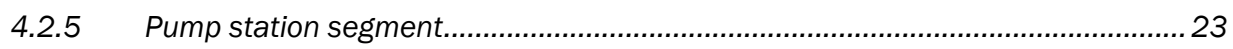

4.2.6 System-wide observations .................................................................................. 23

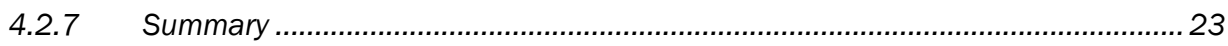

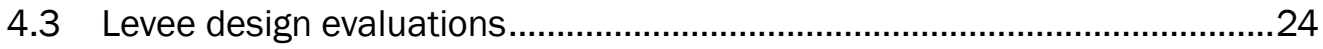

4.4 Rehabilitation................................................................................ 26 


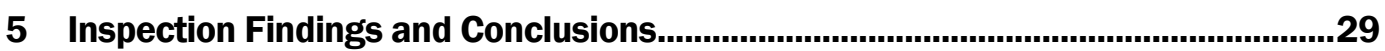

5.1 Key inspection findings and recommendations ........................................ 29

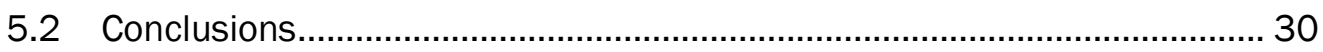

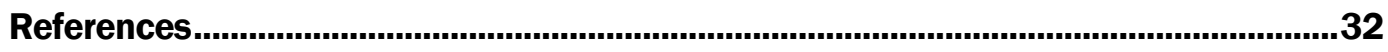

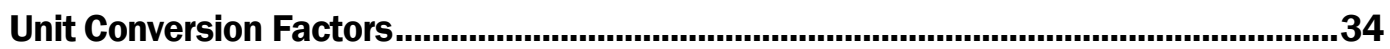




\section{Figures}

\section{Figures}

Figure 1. Santa Margarita levee system along MCAS with levee stationing in meters.

Figure 2. Levee embankment profiles: (A) all soil-cement profile and (B)

combination reinforced earth with soil-cement facing (Winzler and Kelly 2001).

Figure 3. Flood wall details (BergerABAM 2018b).

Figure 4. East segment inspection photos in vicinity of North Lat 33.3105, West Long 117.3439: (A) landside slope with slight weathering, (B) typical transverse crack in levee crest, $(\mathrm{C})$ levee crest with Basilone Road Bridge in background, and (D) observed depressions on riverside toe.

Figure 5. East levee segment: (A) location where levee and guide vane (left) meet, note heavy vegetation on both slopes of guide vane, (B) longitudinal cracking on landside shoulder of levee embankment along the Ranch House road section, $(\mathrm{C})$ weathering of levee slope along the Ranch House road section, and (D) vegetation on riverside slope where the levee meets Vandegrift Boulevard.

Figure 6. Example of severe embankment weathering on the riverside slope along the Ranch House road segment.

Figure 7. View of west levee segment: $(A)$ westerly view looking toward Vandegrift Boulevard, (B) facing east with presence of heavy woody vegetation in the levee right-of-way, (C) standing water on levee toe and presence of vegetation downstream of pump station, and (D) view of right abutment of pump station outflow structure facing west.

Figure 8. Floodwall segment inspection photos: -(A) landside of floodwall looking west, (B) floodwall tie-in to the airfield levee, (C) animal burrows or depressions at the levee tie-in with the airfield segment, and (D) landside of floodwall looking west from floodwall station $500+723$.

Figure 9. Floodwall segment inspection photos: (A) levee embankment with riverside vegetation at floodwall-levee tie-in, $(B)$ alignment of the floodwall looking east, (C) land-side of floodwall looking east, and (D) center of floodwall.

Figure 10. Air station segment inspection photos: $(A)$ view looking east with Basilone Bridge in the distance, $(B)$ view looking west toward hot fueling pad with landside shoulder cracking at the crest, (C) cracking at the fabric-formed concrete interface with the levee crest, and (D) closeup view of cracking at the interface between concrete at the landside crest and fabric slope protection.

Figure 11. View of riverside airfield segment: (A) slight weathering of riverside slope, (B) erosion of surface material at riverside revetment, $(C)$ depression in riverside riprap revetment, and (D) riverside slope and vegetation-free zone at riverside toe looking east.

Figure 12. Areas identified for launchable riprap (yellow double line) in BergerABAM (2019a).

Figure 13. Proposed remediation of levee section (BergerABAM 2019a)........................28

Figure 14. Proposed remediation of floodwall section (BergerABAM 2019a). 


\section{Preface}

This study was conducted for the U.S. Marine Corps Air Station (MCAS) under Project DD1144-2019-GSL-604 for an Independent Technical Review of the Proposed Santa Margarita Levee Rehabilitation Project, Camp Pendleton, CA, MIPR Mo220821MPFE001. The MCAS technical monitor was Dr. Diane Walsh, Environmental Officer, Environmental Department, MCAS, Camp Pendleton, CA 92055.

The work was performed by the Geotechnical Engineering and Geosciences Branch (GEGB), Geosciences and Structures Division (GSD), Geotechnical and Structures Laboratory (GSL), U.S. Army Engineer Research and Development Center (ERDC). At the time of publication, Mr. Christopher G. Price was Chief, GEGB; Mr. James L. Davis was Chief, GSD; Mr. Charles W. Ertle II was Deputy Director of GSL, and Mr. Bartley P. Durst was Director of GSL.

The Commander of ERDC was COL Teresa A. Schlosser, and the Director was Dr. David W. Pittman. 


\section{Introduction}

\subsection{Background}

Personnel from Marine Corps Air Station (MCAS) Camp Pendleton (CP) contacted the Geotechnical Engineering and Geosciences Branch (GEGB), Geosciences and Structures Division (GSD), Geotechnical and Structures Laboratory (GSL) at the Engineer Research and Development Center (ERDC) for an engineering review of a planned levee rehabilitation project along the Santa Margarita River. The levees are owned and maintained by the U.S. Marine Corps (USMC). These levees lower the risk of flooding the MCAS from the Santa Margarita River.

Previous levee inspections rated the levee system as "Unacceptable" due to unwanted vegetation encroaching on the levee right-of-way, which prevents full inspection during flooding, and levee cracking (Terracon and GEI 2012; USACE 2017). Recommendations regarding the levee inspection resulted in a remediation plan being developed by BergerABAM (2019a, 2019b, 2019c, 2019d) for MCAS to increase the rating of the levee system to "Acceptable." The proposed remediation plan for the levees is in the planning-review stage.

Concerns were raised by U.S. Fish and Wildlife (USFW) personnel about the environmental impacts of the remediation measures and the necessity of such actions. Their concerns were whether the planned remediation efforts minimized the impact to the surrounding environment. To address these concerns, USFW personnel requested an engineering review from an independent party. Geotechnical personnel from ERDC were contacted to perform the subject independent engineering review for the planned remediation efforts.

\subsection{Purpose and scope}

The purpose of this report is to describe the activities performed, results obtained, and conclusions made from the independent technical review of past levee inspections and the proposed remediation plan. In support of the technical review, a supplemental ERDC levee inspection was performed on 19 and 20 November 2019 with MCAS personnel. Following the levee inspection, a post-inspection briefing was given to COL Richard T. Anderson, Commanding Officer of MCAS; his staff; and personnel from 
the USFW. The briefing contained the preliminary inspection findings. ERDC personnel were also tasked with reviewing the existing design documents and the planned remediation documents to provide an independent review and opinion on the proposed levee remediation project. In summary, activities performed in support of the independent technical review involved a levee inspection; review of relevant inspection reports, including the planned remediation alternatives; and preparation of this special report.

\subsection{Major project features}

The Santa Margarita levee system lowers the risk of flooding to MCAS Camp Pendleton. The levee system is approximately 14,070 $\mathrm{ft}(4,289 \mathrm{~m})$ long (Figure 1). The height of the levee was designed with $4 \mathrm{ft}(1.2 \mathrm{~m})$ of additional freeboard to reduce the risks associated with a 100-yr storm event. Principal components of the levee system are a soil-cement levee embankment, a concrete flood wall, a guide vane, an earthen channel, a flood corridor, and a buried storm drainage and levee subdrain system at the landside levee toe (not shown).

Figure 1. Santa Margarita levee system along MCAS with levee stationing in meters.

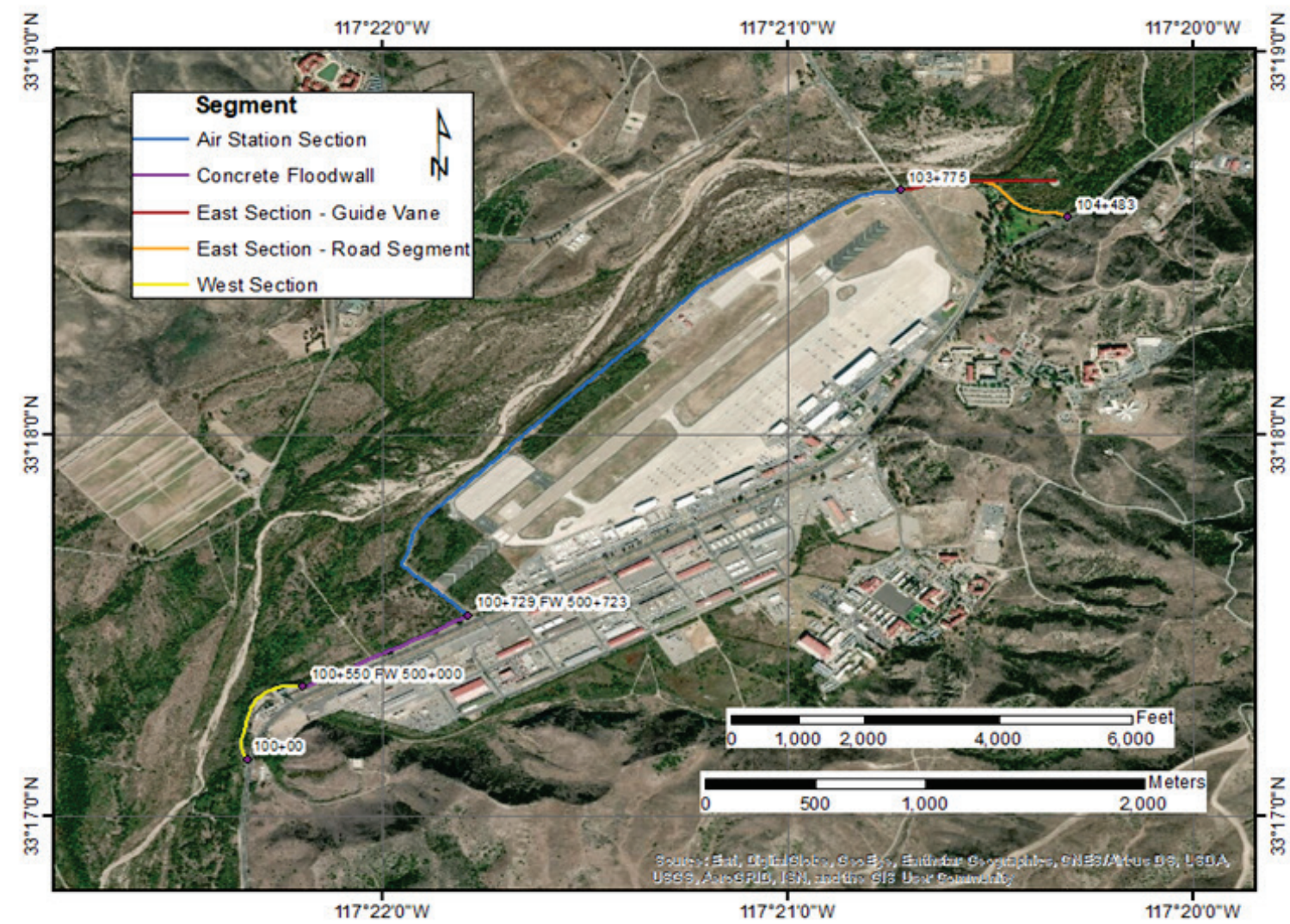


The levee system had been divided into five segments for purposes of describing findings and for consistency with earlier inspections. The segments were as follows: east levee segment (Ranch House Road), west levee segment, floodwall segment, air station segment, and guide vane segment. A pump station was located at the eastern end of the west segment where the concrete floodwall segment begins (Figure 1). The different segments are identified in Figure 1 based on levee stationing in meters. The levee components are further described in the following sections. These components represent the primary elements inspected during the ERDC supplemental inspection.

\subsubsection{Levee embankment}

The levee embankment was constructed of either all soil-cement or a combination of reinforced earth with a soil-cement facing. The all soilcement embankment extends from station $100+00$ to $100+400$ in the west segment, $100+729$ to $100+750$ and $103+600$ to $103+775$ in the air station segment, and $103+775$ to $104+150$ in the east segment. The remaining sections of levee embankment were constructed of a combination of reinforced earth with soil-cement facing. Details of the two profiles are shown in Figure 2. Along the air station, segment modifications were implemented post-construction due to excessive deterioration of the landside embankment slope. The remediation consisted of installing fabric-formed concrete on the slope tied into the crest and levee toe to prevent progression of the deterioration process. 
Figure 1. Levee embankment profiles: (A) all soil-cement profile and (B) combination reinforced earth with soil-cement facing (Winzler and Kelly 2001).

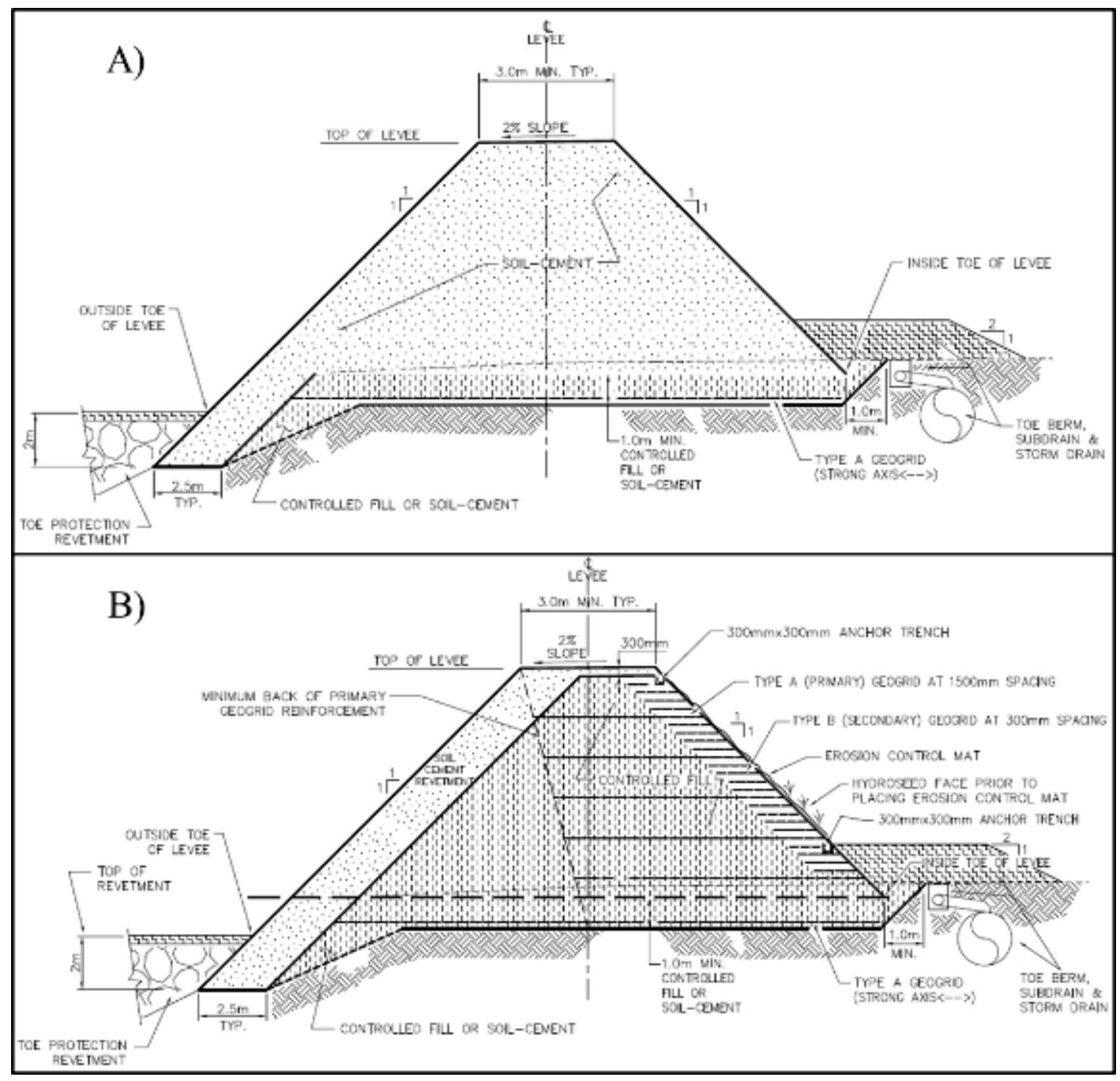

The embankment profiles constructed of all soil-cement were reportedly in areas that were to have a greater risk of being subjected to large hydraulic forces. Additionally, the riverside toe of the levee was protected against scour by incorporation of a rock toe revetment. A landside toe berm and drain were installed to prevent or reduce internal erosion from high river stages.

\subsubsection{Guide vane}

A levee guide vane was constructed to guide the Santa Margarita River to a more direct path through the Basilone Road Bridge area. The guide vane was constructed of soil-cement and extends from levee station 104+075 upstream $990 \mathrm{ft}$ (302 m), as shown in Figure 1. The guide vane prevents 
the high velocity river currents from flowing directly against the levee face. The guide vane embankment design is similar to that shown in Figure 2A.

\subsubsection{Flood wall}

The flood wall was constructed of reinforced concrete and is approximately $15 \mathrm{ft}(3.9 \mathrm{~m})$ high and extends for approximately $2,360 \mathrm{ft}$ (719 m). A typical flood wall section is shown in Figure 3. The flood wall foundation is protected with horizontal rock revetment at the riverside, similar to the levee. Flood wall stationing is different from the levee stationing. At the most westerly point, the flood wall stationing is $500+000$ and the matching levee stationing is $100+550$. At the most easterly point, the flood wall stationing terminates at $500+723$ and the levee stationing resumes at $100+729$.

\subsubsection{Hydraulic design}

The levee system was designed to protect against flows up to the 100-year return period, which during the original design analysis was found to be $64,000 \mathrm{cfs}$. The watershed area was stated to be 715 square miles $(1,852$ square $\mathrm{km})$. The minimum levee height was designed to be $4 \mathrm{ft}(1.2 \mathrm{~m})$ above the hydraulic grade line, with 2.5 feet $(0.76 \mathrm{~m})$ considered freeboard and $1.5 \mathrm{ft}(0.46 \mathrm{~m})$ for sediment accumulation. 
Figure 2. Flood wall details (BergerABAM 2018b).

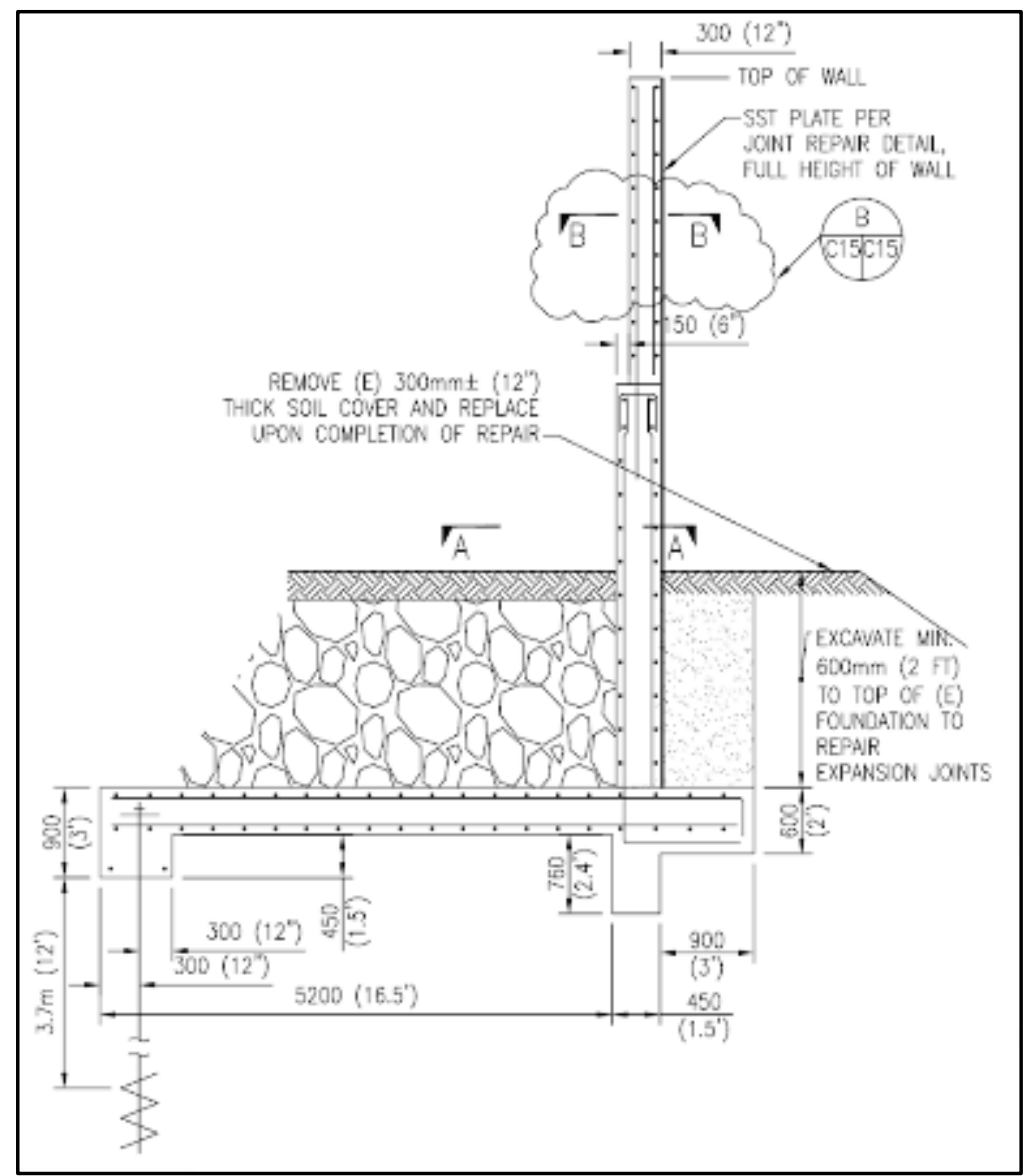




\section{Past Levee Inspections}

\subsection{Introduction}

Previous inspection reports were reviewed for understanding of the levee system and its condition at the time of the inspection and to focus the ERDC field inspection on items that were rated unacceptable (Terracon and GEI 2012; USACE 2017; Winzler and Kelly 2001). The levee inspection reporting is based on the USACE guidance standards and the levee inspection checklist (https://www.usace.army.mil/Missions/Civil-Works/Levee-SafetyProgram/Levee-Inspections/ [2020]).

Two levee inspection reports (Terracon and GEI 2012; USACE 2017) were reviewed prior to the supplemental inspection. The levee system components inspected in the 2012 report consisted of the following: levee east segment, levee west segment, concrete floodwall, and levee air station segment. The components inspected in the 2017 inspection consisted of the same components inspected in 2012 with the addition of the pump station. Both inspections were performed in accordance with the U.S. Army Corps of Engineers (USACE) guidance. Each of the levee components was inspected and rated as acceptable, minimally acceptable, or unacceptable. If any individual levee component was rated as unacceptable, then the project was rated as unacceptable.

\subsection{2 major findings of inspection and rating (Terracon and GEI 2012)}

The MCAS levee system was rated as unacceptable due to the presence of vegetation within the vegetation-free zone. It was deemed that the vegetation was thick enough to impair observation of pertinent levee features, especially during flooding when inspection is most warranted to monitor levee distress.

The major deficiencies for the west segment consisted of the following:

- Unwanted vegetation growth: brush and woody vegetation were observed in the vegetation-free zone.

- Cracking: a transverse crack was observed that extended across the levee crest from the riverside to the landside; crack was noted to be approximately $1 / 8$-in. wide. 
- Inaccessible riprap: the riprap revetment was noted to be hidden by unwanted vegetation growth and could not be inspected.

The major deficiencies for the concrete floodwall were noted to be:

- Unwanted vegetation growth: brush and woody vegetation were observed in the vegetation-free zone.

- Inaccessible riprap: the riprap revetment was noted to be hidden by unwanted vegetation growth and could not be inspected.

The major deficiencies for the air station segment were noted to be:

- Presence of trees greater than 2 in. $(5.08 \mathrm{~cm})$ in diameter in the vegetation-free zone at numerous locations. Presence of brush and other vegetation impaired visibility at numerous locations.

- Presence of year-round cracks at numerous locations in both the repaired areas and the soil-cement in the original levee profile. A crack that was $6 \mathrm{in}$. $(15.24 \mathrm{~cm})$ deep was identified at more than one location. Numerous longitudinal cracks in the crest up to approximately $110 \mathrm{ft}$ $(33.5 \mathrm{~m})$ in length in both the unrepaired and repaired levee sections.

- Sinkholes at the riverside toe of the levee in the riprap revetment were identified. Scour or displacement could not be confirmed due to the presence of heavy vegetation.

The major deficiencies for the east segment consisted of the following:

- Presence of brush and woody vegetation within the vegetation-free zone on the riverside and landside toes of the levee and guide vane that impaired visibility of erosion, seepage, and animal burrows.

A review of the major findings shows that the results of this inspection indicated that the unsatisfactory rating was primarily due to the presence of heavy vegetation.

\subsection{7 inspection major findings and rating (USACE 2017)}

The project was rated as unacceptable due to the presence of vegetation within the vegetation-free zone; it was deemed that the vegetation was thick enough to impair observation of pertinent levee features.

The major deficiencies reported for the east segment are the following: 
- Inappropriate vegetation in the vegetation-free zone on the riverside and landside toes of the levee. Due to vegetation, the riprap revetment could not be inspected.

The major deficiencies reported for the west segment are the following:

- Inappropriate vegetation in the vegetation-free zone on the riverside and landside toes of the levee. Due to vegetation, the riprap revetment could not be inspected.

The major deficiencies reported for the floodwall segment are the following:

- Inappropriate vegetation in the vegetation-free zone on the riverside toe of the floodwall. Due to vegetation, the riprap revetment could not be inspected.

The major deficiencies reported for the pump station are the following:

- No major deficiencies.

The major deficiencies reported for the air station segment are the following:

- Inappropriate vegetation in the vegetation-free zone on the riverside and portions of the landside toes of the levee.

- Cracking along the cap of the fabriform lining.

Review of the major deficiencies from USACE (2017) showed that vegetation encroachment on the levee was the primary deficiency. It was Schnabel's opinion that the levee system was in a minimally acceptable condition at the time of the inspection. This condition was despite some individual components' being rated unacceptable. However, Schnabel concluded that based on strict interpretation of USACE guidelines, the system should be rated as unacceptable. 


\section{ERDC Inspection}

\subsection{Introduction}

Personnel from ERDC inspected the levee system on 19 and 20 November 2019. This inspection was sponsored by the MCAS Environmental Office to obtain an independent technical opinion regarding levee condition and planned remediation efforts to the levee system. The remediation was designed to address the reported deficiencies observed in the levee inspection reports previously described.

The independent technical review was requested to ensure that the remediation efforts were focused on levee safety and did not adversely impact the species previously identified as being endangered more than was necessary to ensure the adequacy of the levee system in regards to reducing the risk of flooding.

The inspection was performed by walking the crest of the levee. The landside toes of the levee were inspected closer where discrepancies were identified and where toe access was permitted. Previous inspection observations by Terracon and GEI (2012) and USACE (2017) were summarized in the previous section, with the primary deficiency being the encroachment of vegetation onto the levee right-of-way, previously preventing full inspection.

The ERDC levee inspection started at the east segment, moved to the west, continued to the floodwall, and was completed at the airfield segment. The four segments were inspected on 19 November and a follow-up inspection of the airfield segment landside toe was conducted on 20 November. The primary focus of the inspection of the levee was the levee embankment and floodwall. The pump station was not inspected for either operational or mechanical features.

\subsection{East segment}

The east segment was bounded by Basilone Road Bridge, Santa Margarita River, and Vandegrift Boulevard (Figure 1, identified as red- and orangecolored segments). The inspection was initiated at Basilone Bridge, and the team moved east from the bridge at approximate levee station $103+775$.

This segment of the levee consisted of the levee reach from station 103+775 
to $104+483$ as well as the levee guide vane. The levee embankment from the bridge to behind the Ranch House was soil-cement and both riverside and landside slopes showed signs of moderate weathering.

Heavy vegetation was present on the guide vane section and in places had to be parted to pass along the crest. On the landside of the levee behind the Ranch House road, the levee embankment was a composite of soil-cement and reinforced earth. In this area, woody vegetation was observed growing out of the landside embankment slope. At regular intervals on the levee crest, transverse cracking was identified. These cracks did not appear to penetrate deeper than the first lift of embankment material, which was six in. $(15.2 \mathrm{~cm})$ or less.

Figure 4 shows photos of the levee between the bridge and the Ranch House road (observation point at North Lat 33.3105, West Long 117.3439). Figure 4A shows the landside slope of the soil-cement levee with slight weathering. Figure 4B shows typical transverse cracking in the levee crest. Figure $4 \mathrm{C}$ shows the soil-cement embankment crest in very good condition. Figure 4D shows depressions at the riverside toe in the riprap revetment. The depressions varied in size with the largest being approximately $8 \mathrm{in} .(20.3 \mathrm{~cm})$ wide and $1 \mathrm{ft}(30.5 \mathrm{~cm})$ long with a depth of 8-12 in. (20-31 cm). The depressions at most locations contained riprap, but most of the soil cover was eroded away. These types of depressions were evident along the entire levee system with the density of observations being greatest along the airfield segment. In some locations, observations could not be made due to the presence of heavy vegetation. 
Figure 3. East segment inspection photos in vicinity of North Lat 33.3105, West Long 117.3439: (A) landside slope with slight weathering, (B) typical transverse crack in levee crest, (C) levee crest with Basilone Road Bridge in background, and (D) observed depressions on riverside toe.

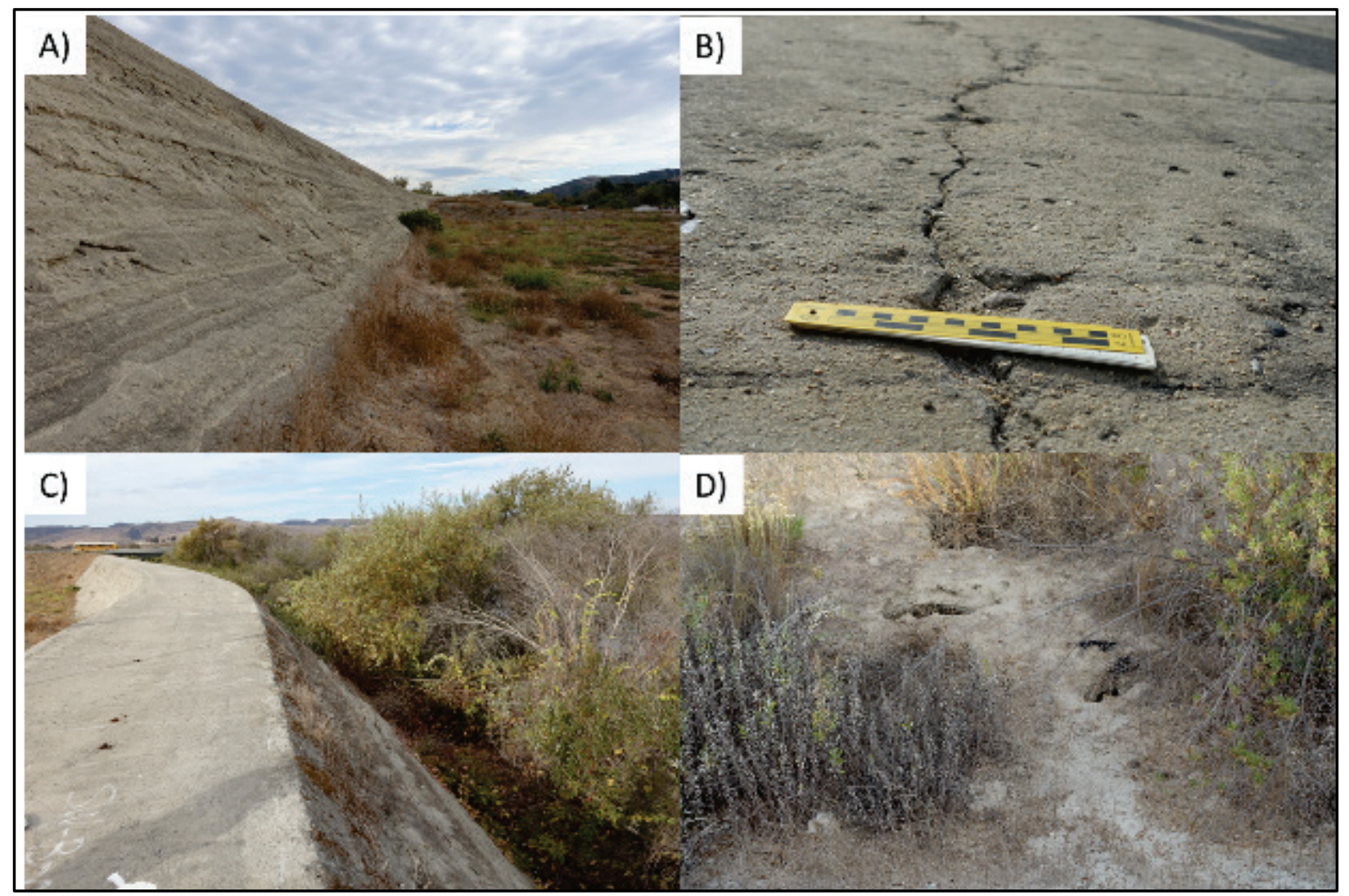

Figure $5 \mathrm{~A}$ shows vegetation conditions where the levee guide vane meets the levee road embankment, with the presence of heavy vegetation at both toes of the levee. Figure 5B shows a longitudinal crack $46 \mathrm{ft}(14 \mathrm{~m})$ in length near the landside shoulder of the levee crest, a short distance from the road and guide vane intersection. The likely cause of the cracking is vegetation growing out of the embankment slope. Additionally, an old irrigation system was observed at the levee toe, which was used to water planted vegetation on Ranch House grounds. The system did not appear operational at the time of inspection, but watering close to the levee prism in the past may have contributed to the existing conditions. Figure $5 \mathrm{C}$ shows an example of more severe embankment weathering on the riverside levee slope along the Ranch House road leading to the guide vane intersection. Finally, Figure $5 \mathrm{D}$ shows vegetation in the vegetation-free zone at the termination of the levee at Vandegrift Boulevard. Figure 6 shows another example of severe weathering to the levee slope. 
Figure 4. East levee segment: (A) location where levee and guide vane (left) meet, note heavy vegetation on both slopes of guide vane, (B) longitudinal cracking on landside shoulder of levee embankment along the Ranch House road section, (C) weathering of levee slope along the Ranch House road section, and (D) vegetation on riverside slope where the levee meets Vandegrift Boulevard.

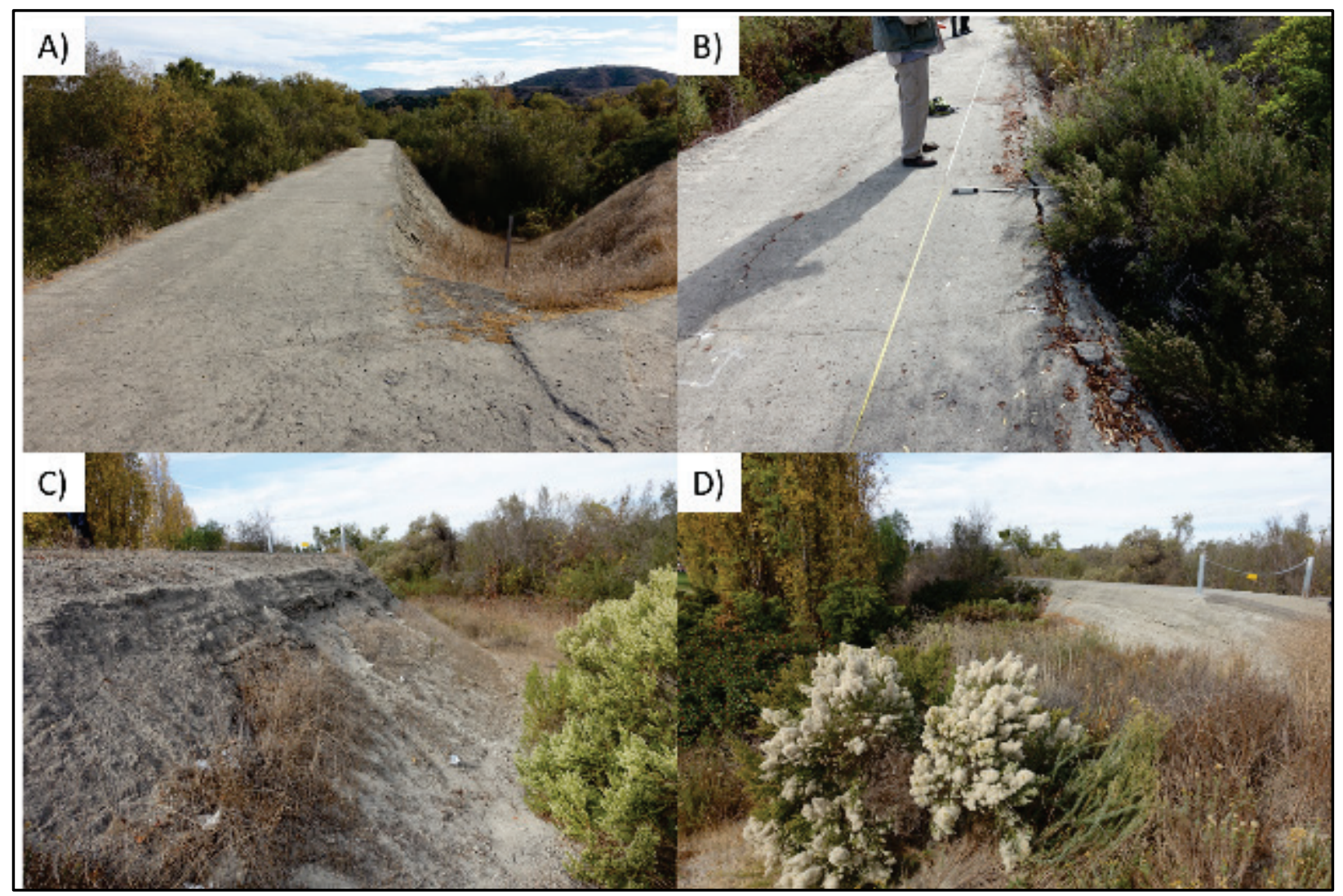

Figure 5. Example of severe embankment weathering on the riverside slope along the Ranch House road segment.

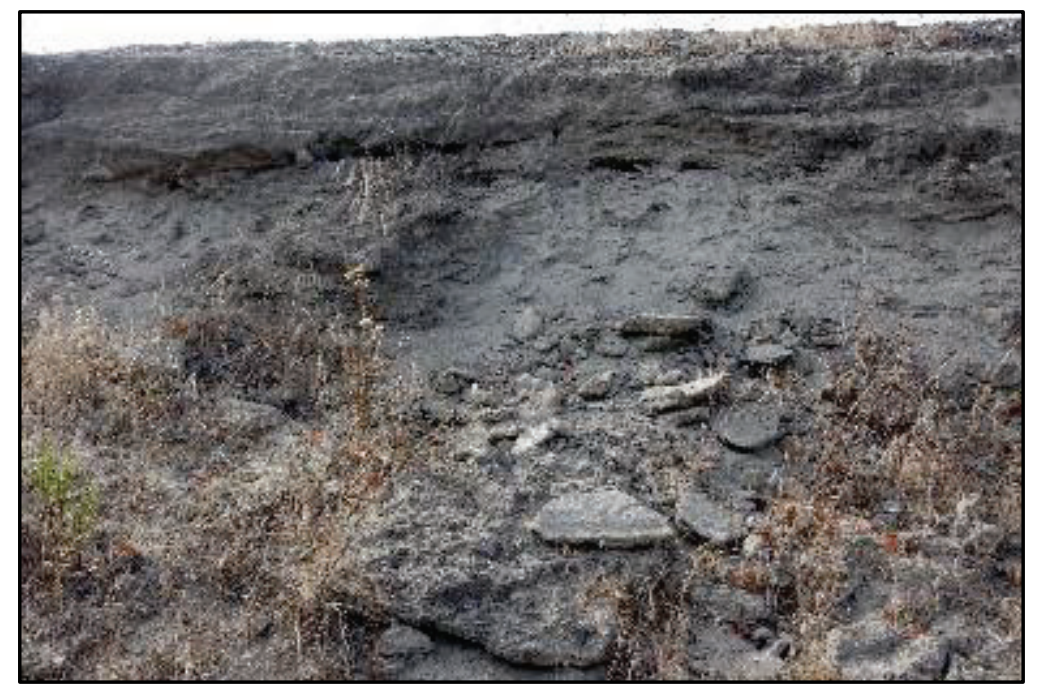




\subsubsection{East levee segment key findings}

Key findings from the inspection of the east levee segment are as follows:

1. Vegetation is adversely impacting the levee. Instances where woody vegetation is growing out of the embankment (near the Ranch House reach) are likely causing deformation and sliding of the landside slope. The presence of woody vegetation at the riverside toe of the levee is likely causing deformation of the riprap revetment. This condition could cause preferential seepage paths that would provide concentrated seepage pathways beneath the embankment. Additionally, the presence of both woody and weedy vegetation inhibits observations during flooding and may prevent observation of levee distress that could lead to failure of the levee that otherwise might have been prevented through flood-fight methods. Levee inspections during flood conditions are critical and important to ensure levee safety.

2. Weathering of the embankment side slopes needs remediation before further loss of embankment material occurs. If left unchecked for the long term, this condition could lead to a need to replace the levee embankment entirely. Likely remediation would involve regrading the slope with the addition of soil-cement materials and/or armoring the slope with filter cloth and riprap or articulated concrete mats.

3. Depressions in the riverside riprap revetment should be further inspected following vegetation removal and an accurate remediation plan should be initiated.

\subsection{West segment}

The west levee segment is bounded by Vandegrift Boulevard and the levee floodwall (Figure 1). This levee segment passes behind the pump station. It begins at levee station $100+000$ and terminates at station $100+729$. The levee embankment was constructed of soil-cement from Vandegrift Boulevard to the left abutment of the pump station outflow structure. The levee embankment was constructed of a combination soil-cement and reinforced earth from the right abutment of the pump station outflow structure to the start of the floodwall segment.

This embankment is in much better condition than the east segment. Both the landside and riverside toe of the levee contained woody vegetation. 
However, landside vegetation was not as dense as that observed on the riverside toe of the levee (Figures $7 \mathrm{~A}$ and $7 \mathrm{~B}$ ). Moderate weathering of the soil-cement embankment was observed at some of the lift contacts on the riverside of the levee (Figure $7 \mathrm{C}$ ). Near the pump station, standing water was observed at the riverside toe of the levee both upstream and downstream of the pump station (Figures $7 \mathrm{C}$ and $7 \mathrm{D}$ ). Transverse cracking was identified in multiple locations, extending from the riverside toe across the levee to the landside toe. Close examination of Figure $7 \mathrm{~A}$ shows an example of the transverse cracking that is present. The cracking was tight and did not appear to be recently formed. The presence of woody vegetation and standing water on the riverside toe restricted access and inspection of the riverside riprap revetment.

Figure 6. View of west levee segment: (A) westerly view looking toward Vandegrift Boulevard, (B) facing east with presence of heavy woody vegetation in the levee rightof-way, (C) standing water on levee toe and presence of vegetation downstream of pump station, and (D) view of right abutment of pump station outflow structure facing west.

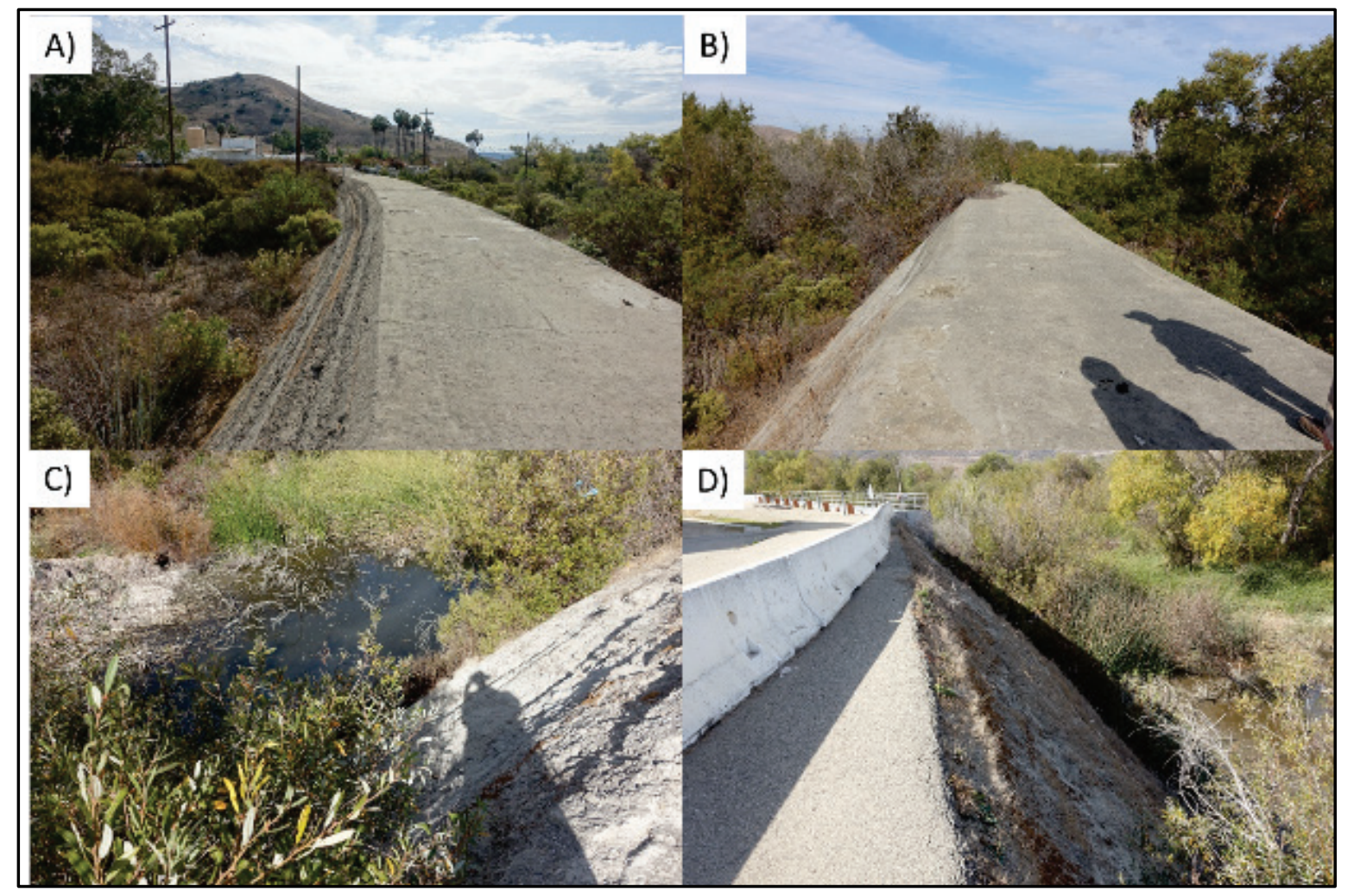

\subsubsection{West levee segment key findings}

Key findings from the inspection of the west levee segment are as follows: 
1. Vegetation is adversely impacting the levee. The presence of woody vegetation at either toe of the levee is likely causing deformation of the riprap revetment that could cause preferential seepage paths beneath the embankment. Additionally, the presence of both woody and weedy vegetation inhibits observations during flooding and may prevent observation of levee distress that can lead to failure of the levee that otherwise may have been prevented by observation and flood fighting (e.g., sand-bagging boils).

2. Standing water on the riverside levee toe should be investigated. It is likely that the culprit is a blocked drainage ditch. Either the blockage is due to vegetation, or the ditch is silted in. Comments made by public works staff during the ERDC inspection indicated that standing water is a recent development. This condition should be investigated to ensure that good drainage is maintained to facilitate inspection during dry periods. Maintenance to restore drainage function is important as, left unchecked, this condition will create future environmental issues and establish an unwanted precedence where none previously existed.

\subsection{Floodwall segment}

The floodwall segment had its own stationing independent of the levee stationing. The floodwall stationing began at station $500+000$ and terminates at station $5 \mathrm{OO}+723$, which corresponded to levee stationing $100+550$ and 100+729, respectively. The alignment of the floodwall appeared to be as designed, with no noticeable alignment issues. The rehabilitated joints noted in the Terracon and GEI (2012) inspection report appeared to be in good condition, with no noticeable weathering. The landside of the floodwall was well-kept, and vegetation was trimmed on a regular schedule. A landside drainage ditch appeared to be in good condition and was also well-maintained.

Figures $8 \mathrm{~A}$ to $8 \mathrm{D}$ show the riverside and landside of the floodwall as well as the landside drainage ditch. Numerous small rodent burrows were observed within 5 to $10 \mathrm{ft}$ ( 1.5 to $3 \mathrm{~m}$ ) landside of the floodwall. Figure 8A shows the vegetation at the downstream levee-floodwall tie-in. Figures $8 \mathrm{~B}$ and $8 \mathrm{C}$ are views looking east, while Figure $8 \mathrm{D}$ shows the floodwall looking west. Vegetation is growing against the riverside of the floodwall in all these views.

Figures 9A through 9D show different views of the floodwall near its intersection with the airfield segment. Figure 9A is a view looking west and 
shows woody and weedy vegetation on the riverside of the floodwall. Also noteworthy at this location were large depressions in the riverside riprap revetment along the base of the floodwall. Depressions were mainly observed on the riverside of the floodwall and within a few feet of the wall. Figure $9 \mathrm{C}$ shows an example of the type of depressions that were observed. The largest observed depression was approximately $3.5 \mathrm{ft}(1 \mathrm{~m})$ long and 1 $\mathrm{ft}(0.3 \mathrm{~m})$ wide, with a depth greater than $1 \mathrm{ft}(0.3 \mathrm{~m})$. Complete inspection of the riverside floodwall was inhibited by the presence of heavy vegetation. Figure $10 B$ shows the overlap between the floodwall and the levee at levee station $100+729$.

Figure 7. Floodwall segment inspection photos: -(A) landside of floodwall looking west, (B) floodwall tie-in to the airfield levee, (C) animal burrows or depressions at the levee tie-in with the airfield segment, and (D) landside of floodwall looking west from floodwall station $500+723$.

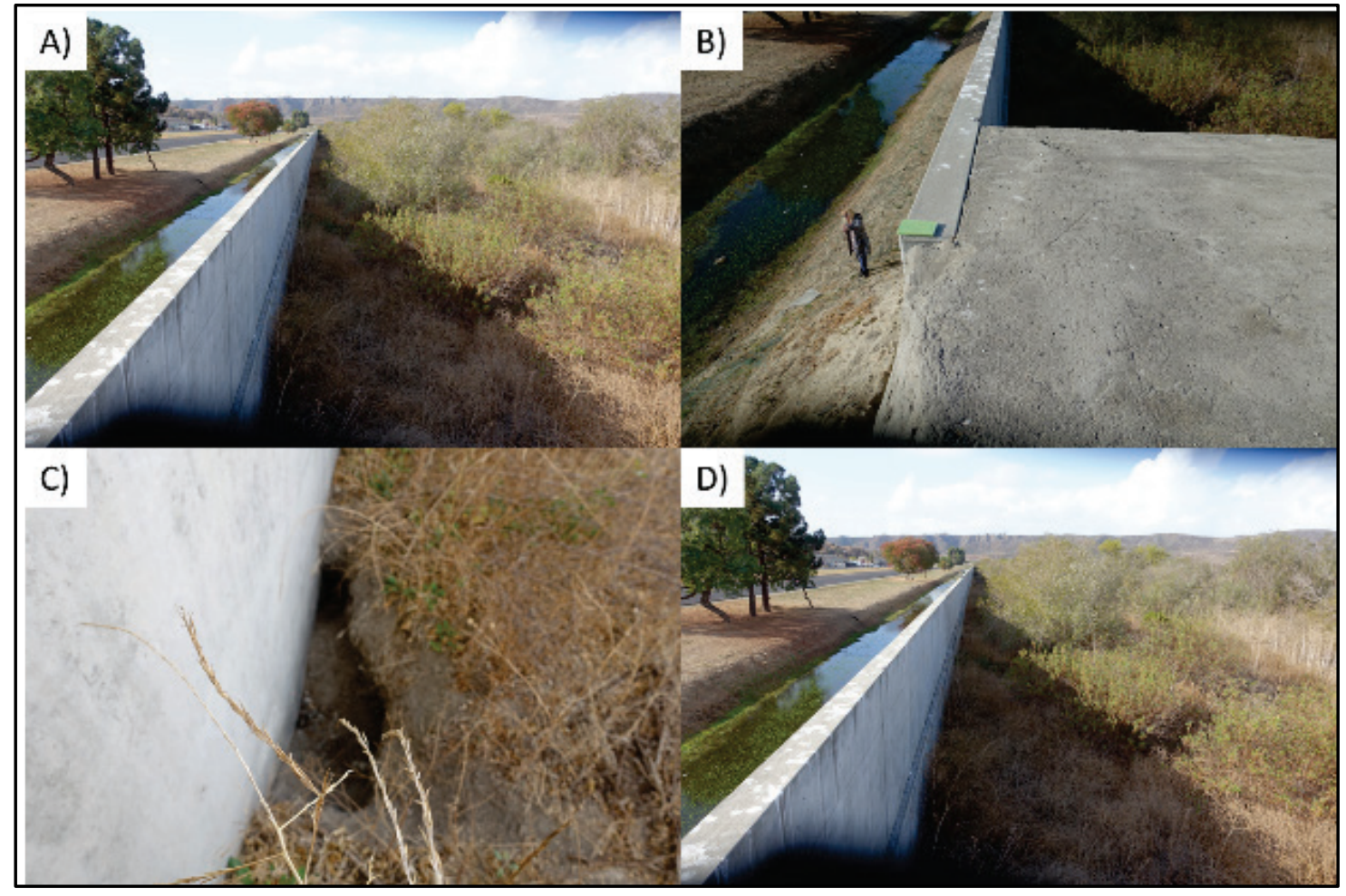


Figure 8. Floodwall segment inspection photos: (A) levee embankment with riverside vegetation at floodwall-levee tie-in, (B) alignment of the floodwall looking east, (C) land-side of floodwall looking east, and (D) center of floodwall.

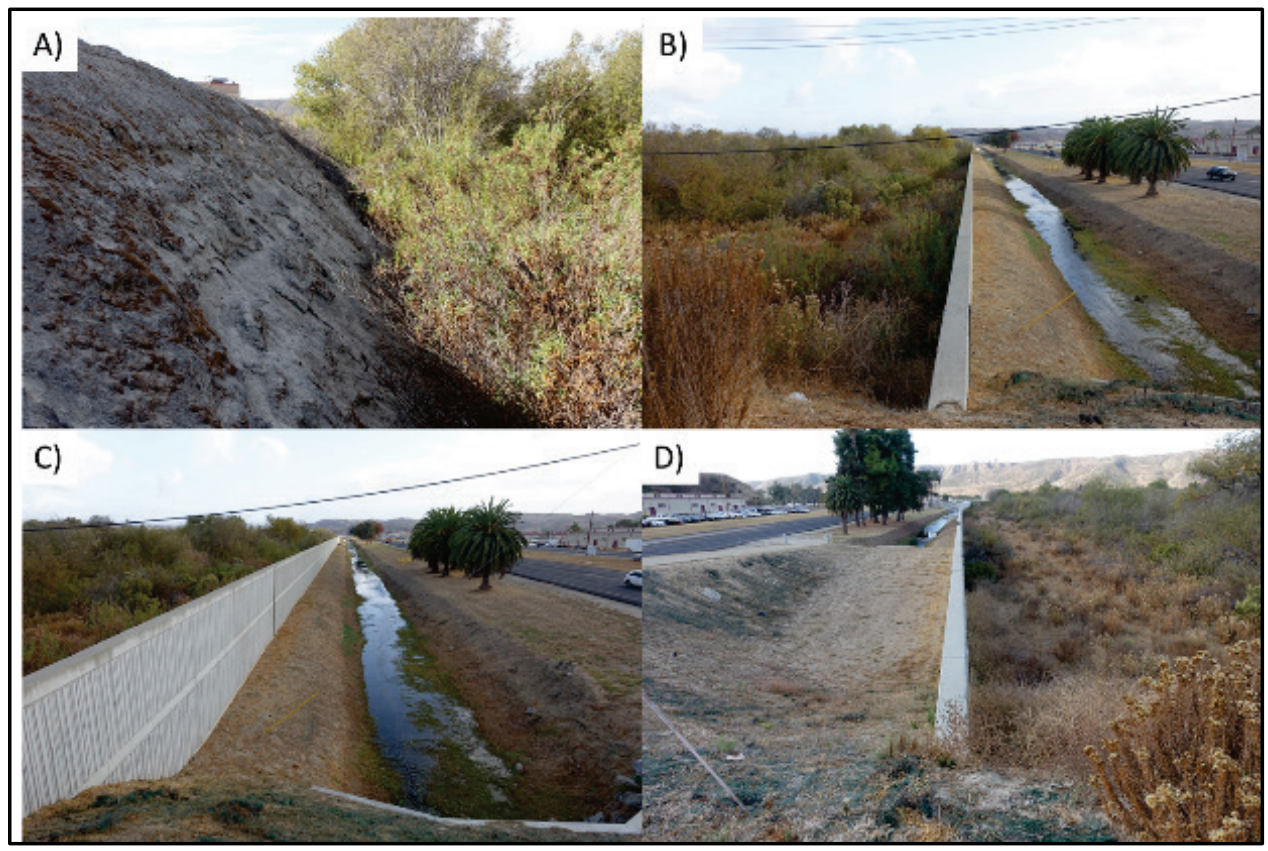

\subsubsection{Floodwall segment key findings}

Key findings from the inspection of the floodwall segment are as follows:

1. Both weedy and woody vegetation on the riverside of the levee is inhibiting observation of the riprap revetment. This vegetation makes riverside inspection of the floodwall difficult.

2. Numerous depressions were observed on the riverside of the floodwall. These depressions are similar to those observed in the east segment.

\subsection{Air station segment}

The airfield levee segment extended from station 100+729 to station $103+775$. The levee embankment in this segment was constructed of composite soil-cement and a geogrid reinforced earth fill (Figures 10A to 10D). The reinforced earth fill was located on the landside slope; due to weathering and poor performance, it had to be remediated. Remediation of the landside slope consisted of installed fabric-formed concrete on the slope. Cracking at the interface of the fabric-formed concrete and the soilcement portion of the crest was observed along the extent of this segment (Figures 10B to 10D). 
Figure 9. Air station segment inspection photos: $(A)$ view looking east with Basilone Bridge in the distance, $(B)$ view looking west toward hot fueling pad with landside shoulder cracking at the crest, (C) cracking at the fabric-formed concrete interface with the levee crest, and (D) closeup view of cracking at the interface between concrete at the landside crest and fabric slope protection.

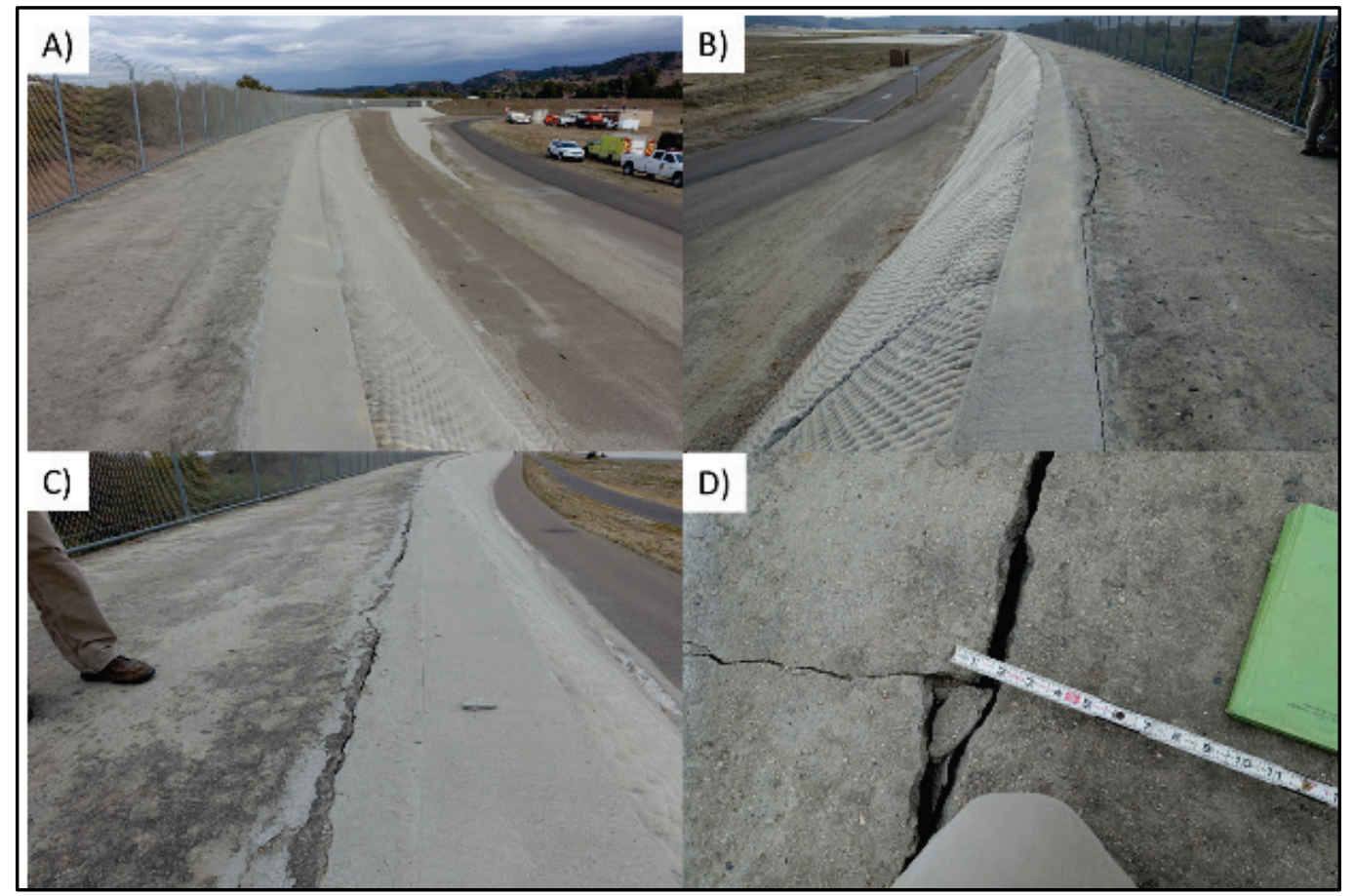

Crack monitoring gauges were observed at several locations, and project personnel indicated that they were monitoring the crack dimensions: current conditions were reported to be stable.

The landside part of the levee in the air station was well-maintained and clear of vegetation. An access road runs parallel to the landside toe, and no distress was visible in the asphalt. A drainage ditch located near the aircraft refueling pad had vegetation that made observations during highwater events difficult.

Moderate weathering of the riverside embankment slopes was observed, along with numerous depressions of the revetment where rock was absent and/or assumed to have significantly settled (see Figures 11A through 11D). Woody vegetation was observed growing in the vegetation-free zone at the riverside toe along much of this segment and from the riverside riprap revetment. Figures $11 \mathrm{~A}$ and $11 \mathrm{D}$ are areas where woody vegetation is absent and permits better close inspection of riverside conditions, providing mowing of grass-covered areas is periodically performed. 
Figure 10. View of riverside airfield segment: (A) slight weathering of riverside slope, (B) erosion of surface material at riverside revetment, (C) depression in riverside riprap revetment, and (D) riverside slope and vegetation-free zone at riverside toe looking east.

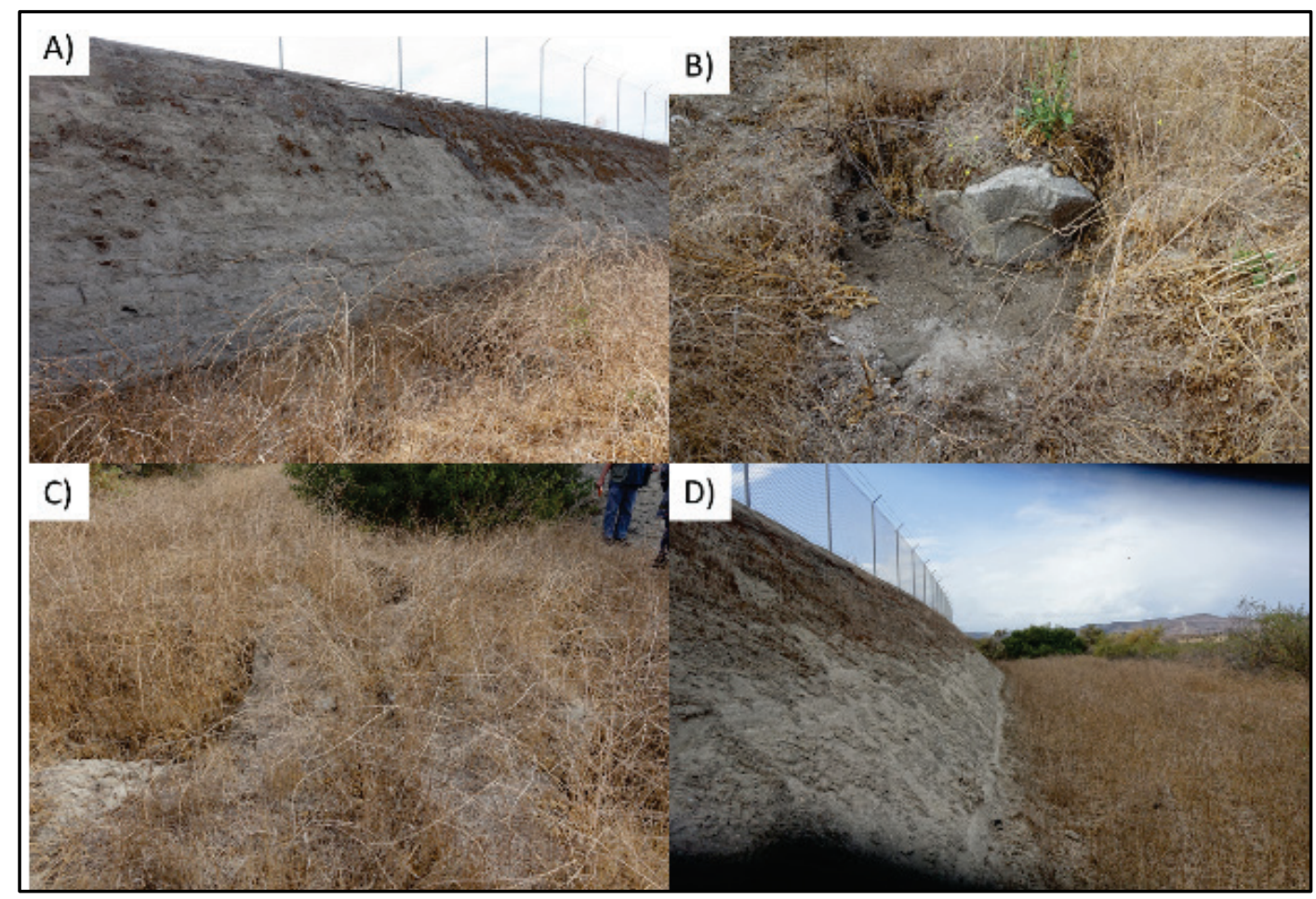

\subsubsection{Air station levee segment key findings}

Key findings from inspection of the airfield levee segment are as follows:

1. Vegetation is adversely impacting the levee right-of-way. The presence of woody vegetation on the riverside toe of the levee is likely causing deformation of the riprap revetment and could provide preferential seepage paths beneath the embankment. Additionally, the presence of both woody and weedy vegetation inhibits observations during flooding and may prevent observation of levee distress that can lead to failure of the levee that otherwise may have been prevented.

2. Crack monitoring should be continued at the interface of the fabricformed concrete and the levee crest material.

3. Depressions in the riprap revetment should be inspected following vegetation removal, and a remediation plan should be initiated. 


\section{Rehabilitation Review}

\subsection{Introduction}

Rehabilitation of the levee system protecting the MCAS is currently in the planning stages. A concept design has been submitted and is currently undergoing internal review by MCAS personnel. ERDC personnel were requested to review the design submittal to assess the applicability of the design and provide an expert opinion as to whether this design will address the current "Unacceptable" rating of the levee system. The rating resulted from previous inspections conducted in 2012 and 2017 (Terracon and GEI 2012; USACE 2017). BergerABAM (2019d) submitted the current design plans to MCAS to address the remediation. The proposed plan was supported by comprehensive field investigations including soil sampling, laboratory soil testing, and engineering studies (BergerABAM 2018c, 2018f).

\subsection{Levee deficiencies}

The primary deficiency identified in the previous inspections was the encroachment of vegetation onto the levee footprint. Additional deficiencies included depressions in the riverside riprap revetment and cracking of the crest on the airfield segment. A full list of major deficiencies from the 2012 and 2017 inspection report is described in a previous section. An additional inspection was conducted by BergerABAM (2018f), using subcontractor Shannon and Wilson in 2018. The major findings from this inspection are listed below by levee segment.

\subsubsection{East levee embankment}

1. Friable nature of portions of the soil-cement could be susceptible to erosion during a flood event. It appears likely that the erosion would not prevent the levee from functioning during the flood event, but performance during subsequent flood events cannot be predicted.

2. Riprap was installed starting at the riverside toe and extending approximately $50 \mathrm{ft}$ riverward to protect the levee from scour. The apparent gap-graded nature of the riprap and the observed scour hole located at Basilone Road Bridge result in questions of the likely performance of the riprap during flood events. Again, it appears likely that the riprap would reduce scour adjacent to the levee 
during a single flood event, but performance during subsequent flood events cannot be predicted.

\subsubsection{Air station levee segment}

1. The friable nature of portions of the soil-cement could be susceptible during a flood event. It appears likely that the erosion would not prevent the levee from functioning during the flood event, but performance during subsequent flood events cannot be predicted.

2. Riprap was installed starting at the riverside toe and extending approximately $50 \mathrm{ft}$ riverward to protect the levee from scour. The apparent gap-graded nature of the riprap and observed scour result in questions of the likely performance of the riprap during flood events. Again, it appears likely that the riprap would reduce scour adjacent to the levee during a single flood event, but performance during subsequent flood events cannot be predicted.

3. The crack between the soil-cement and the fabric-form concrete facing is a concern only in that it could be an indicator of additional problems occurring beneath the surface. The rigid nature of the fabric-form concrete means that it could bridge voids or soft areas with little or no surface expression. While researchers do not have evidence that voids or soft areas exist, the larger cracks warrant concern. This condition will be further examined during upcoming phases of remediation.

\subsubsection{Flood wall segment}

1. Riprap was installed extending approximately $50 \mathrm{ft}$ riverward of the riverward edge of the flood wall footing to protect from scour. The apparent gap-graded nature of the riprap results in questions regarding the likely performance of the riprap during flood events. It appears likely that the riprap would somewhat limit scour adjacent to the floodwall during a single flood event, but performance during subsequent flood events cannot be predicted.

\subsubsection{West levee segment}

1. The friable nature of portions of the soil-cement could be susceptible to erosion during a flood event. It appears likely that the erosion would not prevent the levee from functioning during the 
flood event, but performance during subsequent flood events cannot be predicted.

2. Riprap was installed starting at the riverside toe and extending approximately $50 \mathrm{ft}$ riverward to protect the levee from scour. The apparent gap graded nature of the riprap results in questions regarding the likely performance of the riprap during flood events. Again, it appears likely that the riprap would reduce scour adjacent to the levee during a single flood event, but performance during subsequent flood events cannot be predicted.

\subsubsection{Pump station segment}

No conditions were observed to indicate that the pump station would not function as designed.

\subsubsection{System-wide observations}

1. At a minimum, all unwanted vegetation that is in contact with the levee embankment or the floodwall should be removed to limit additional damage to the embankment. This minimum also applies to the area adjacent to the Ranch House; however, it is understood that removal of this vegetation will be difficult because it is a culturally protected resource.

2. It was observed that animal burrows exist throughout the length of the levee system. Most of the burrows were located adjacent to the levee or floodwall, but some were observed in the actual levee embankment. Complete control of burrowing animals seems unlikely along this levee. At a minimum, researchers recommend that all burrows in the levee embankment be repaired and that additional controls be implemented to prevent additional burrows within the embankment.

\subsubsection{Summary}

Results of the 2018 inspection by Shannon and Wilson (BergerABAM 2018f) do not differ from previous inspections. The levee deficiencies identified in the 2018 inspections provided a framework for developing a rehabilitation design. 


\subsection{Levee design evaluations}

In order to develop the rehabilitation design, an evaluation of the current levee conditions was necessary. As part of this effort, the following evaluations were conducted: freeboard, scour, seismic, seepage, and stability. Evaluation results were reported in BergerABAM (2018d) and were supported by site investigations, which included test pits, soil borings and sampling, and cone penetration tests (BergerABAM 2018c, 2018f).

The freeboard evaluation was attained using an updated hydrologic engineering center river analysis system (HEC-RAS) model from the subcontractor WEST Inc., and the method was reported in BergerABAM (2018e). Results of this hydraulic evaluation indicate that the levee is adequate and no elevation modification is needed. The scour evaluation was conducted using the results from the WEST analysis. Results of this evaluation indicate that the current riprap revetment is unreliable and should be replaced.

The seismic hazard evaluation was conducted using a peak ground acceleration of $0.22 \mathrm{~g}$ and an earthquake magnitude of 6.5 for the operating basis earthquake (OBE). The site characterization of the site indicated that the foundation of the levee consists of clean sands, and liquefaction may be an issue. A liquefaction analysis was conducted, and it was found that the settlement from liquefaction would be between 1 and 7 in. $(0.4$ and $2.9 \mathrm{~cm})$. It was concluded from these results that the probability of an earthquake occurring at the same time as a flood event is extremely low. Therefore, it was concluded that minor settlements due to liquefaction would not cause a levee failure during flooding. Although reliability issues may arise, a levee inspection following an earthquake of this size would be warranted.

The seepage analysis was conducted using finite element software and steady-state conditions. Steady-state conditions are normally conducted in accordance with USACE guidance. However, full steady-state conditions may not occur due to the short duration of loading. Results of the seepage analysis indicate that a drainage ditch on the landside of the floodwall would likely incur seepage and piping due to high exit gradients. These high exit gradients were associated with a semi-impervious layer. However, this layer may not be continuous, or it may become very thin at the bottom of the drainage ditch. If a clean sand layer exists at the bottom of the drainage ditch with no impervious cover, free drainage of seepage would occur and excess pressures would not develop. A secondary issue 
may arise with erosion of foundation material. Therefore, monitoring of the drainage ditch during flood events is highly recommended. If the semiimpervious foundation layer does exist in the drainage ditch, then calculated exit gradients would be well in excess of USACE guidance. The calculated gradient in this case was found to be 1.7 for the 100-yr event, and USACE guidance recommends a value of less than 0.5 (USACE 2005).

Stability of the levee system was investigated by performing twodimensional limit equilibrium analysis. The pore pressures were imported from the seepage analysis, and shear strengths were assigned based on laboratory testing and empirical relations. A majority of the analysis resulted in factors of safety well in excess of those recommended by USACE guidance. Analyses performed on the floodwall sections with the drainage ditch on the landside resulted in values less than 1.0. A value less than 1.0 indicates failure of the section. Values of less than 1.0 were calculated for both the 100-yr and 20-yr flow events. It should be noted that this project has withstood a 20-yr flow event in the past and experienced no adverse floodwall displacements. Successful past performance could indicate one of the following about these models:

- Assigned shear strengths are too low,

- Steady-state conditions did not develop,

- Interpreted stratigraphy was not accurate, or

- Hydraulic conductivity values were too high.

Review of the assigned shear strength values appears reasonable, and the selected hydraulic conductivity values were reasonable for the types of soils present in the levee foundation. It is more likely that steady-state conditions were not reached in previous flood events. Review of the WEST Inc. hydraulic analysis (BergerABAM 2018e) indicates that the hydrograph peak will likely last a matter of hours rather than days. Longer loadings that could approach steady-state conditions are more apt to correspond to flood events greater than a 100-yr event, which was the design condition for the original levee construction. The best course of action would be to monitor the levee system closely during large flood events as well as conduct postflood inspections.

The levee evaluation report by Shannon and Wilson (BergerABAM 2018d) recommended that scour protection be installed or remediated, a pressure 
relief system be installed landside of the floodwall, and unwanted vegetation be removed within $15 \mathrm{ft}(4.6 \mathrm{~m})$ of the levee toe.

\subsection{Rehabilitation}

Results of the levee evaluation, site investigation, hydraulic evaluation, design, and inspection reports were used to perform a remediation alternative analysis, and these results were reported by Shannon and Wilson (BergerABAM 2019c; 2018a). Recommendations from this report were as follows:

- Construct an access path on the riverside of the levee.

- Selectively abandon the existing perforated sub-drain located at the landside toe of the levee.

- Install launchable riprap on the riverside slope and toe of the levee and floodwall.

- No remediation of the underseepage was recommended.

Additionally, the basis of design was reported in BergerABAM (2019a) with the following elements of design:

1. Install launchable riprap at select locations for erosion control.

2. Construct access path for maintaining the riverside toe and launchable riprap.

3. Abandon existing perforated sub-drain along the levee landside toe by combination of grouting and removal.

4. Clear vegetation within the vegetation-clear zone.

5. Establish construction access, hauling, and staging to carry out repairs.

6. Repair existing cracks in the crest associated with the air station segment.

Installation of the launchable riprap will address issues associated with scour and the observed depressions in the current riprap revetment. Locations identified where launchable riprap are to be installed are shown in Figure 12. Figures 13 and 14 show the design of the launchable riprap as well as the access path for the levee and floodwall sections (BergerABAM 2019a). The proposed design will remediate the existing riprap with the launchable riprap design. 
As scour occurs, the riprap is designed such that gravity will force the riprap at higher elevations to flow into the potential scour hole, arresting further progression. This remediation addresses two deficiencies: it will protect the riverside slope from direct contact by weathering and erosion, which is slowly degrading the embankment, and it will also provide a dynamic response to possible scour induced by high flow events.

Figure 11. Areas identified for launchable riprap (yellow double line) in BergerABAM (2019a).

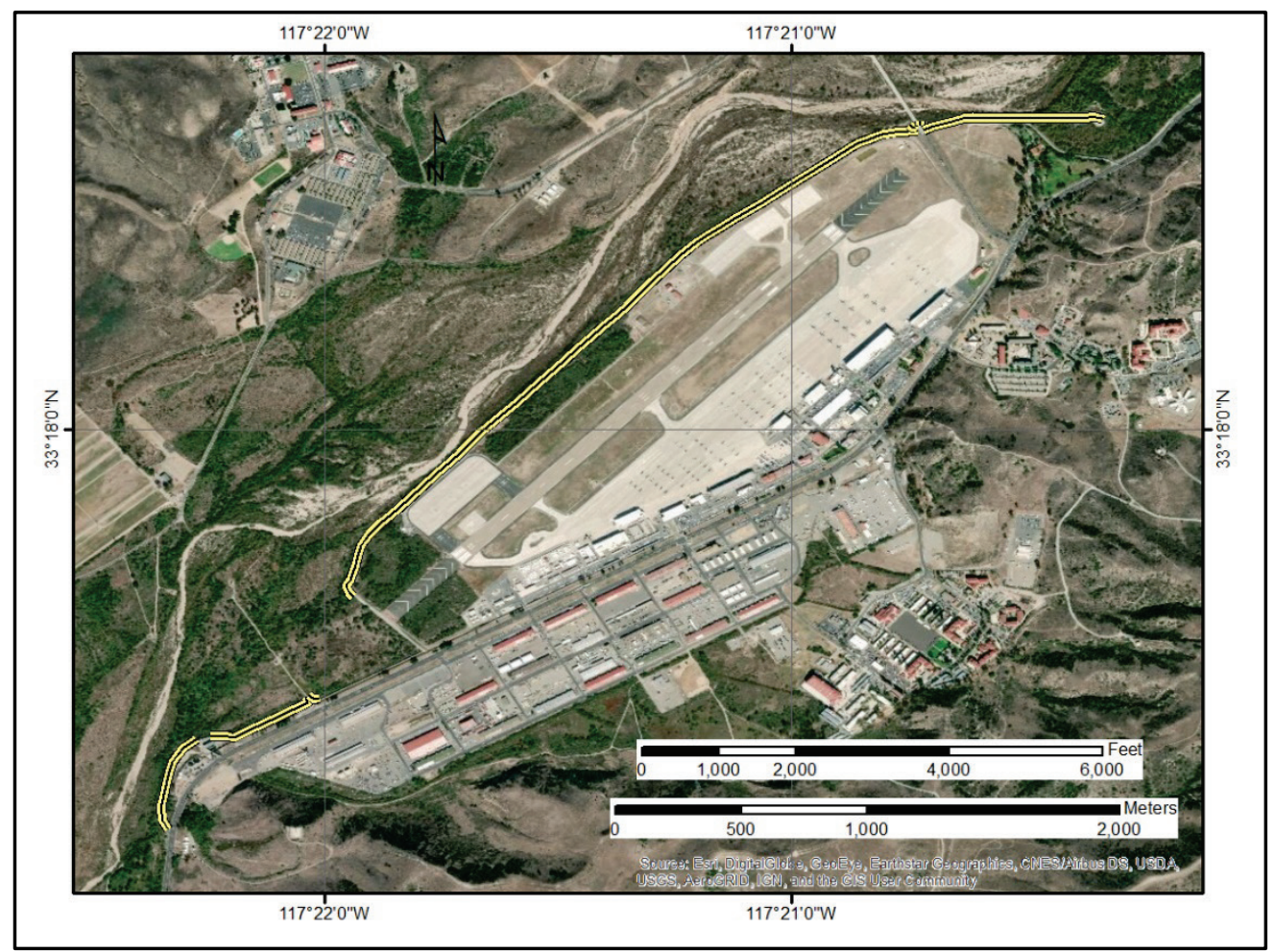

The cracking identified in previous inspections will be addressed by the enlarging and grouting of existing cracks. The geophysical investigation provides a good idea of the extent of cracking, and project MCAS personnel have been monitoring the crack progression, both of which indicate that voids do not exist beyond the crest. Therefore, this remediation is warranted and will prolong the design life of the fabricformed concrete located on the landside slope of the air station levee.

Construction of the launchable riprap and an access path will require clearing of vegetation in the recommended vegetation-clear zone. The vegetation-free zone is recommended to be $15 \mathrm{ft}(4.6 \mathrm{~m})$ (USACE 2014). Establishing the path will allow for ease of maintenance of the vegetation-clear zone and allow for better monitoring access of the riverside slope and the toe of the levee. 
Investigations of the perforated subdrain located on the landside levee toe indicate this original design feature is in disrepair and inoperable. Geotechnical evaluations of the levee design for the remediation indicated that this feature is not necessary.

Figure 12. Proposed remediation of levee section (BergerABAM 2019a).

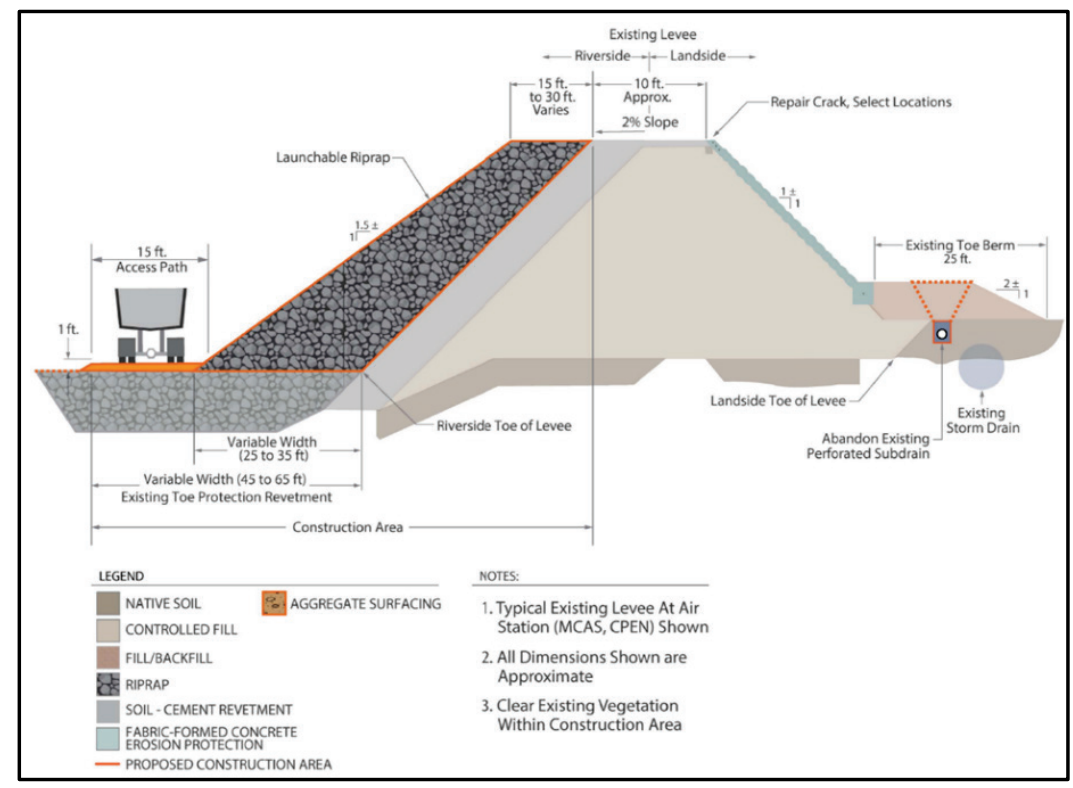

Figure 13. Proposed remediation of floodwall section (BergerABAM 2019a).

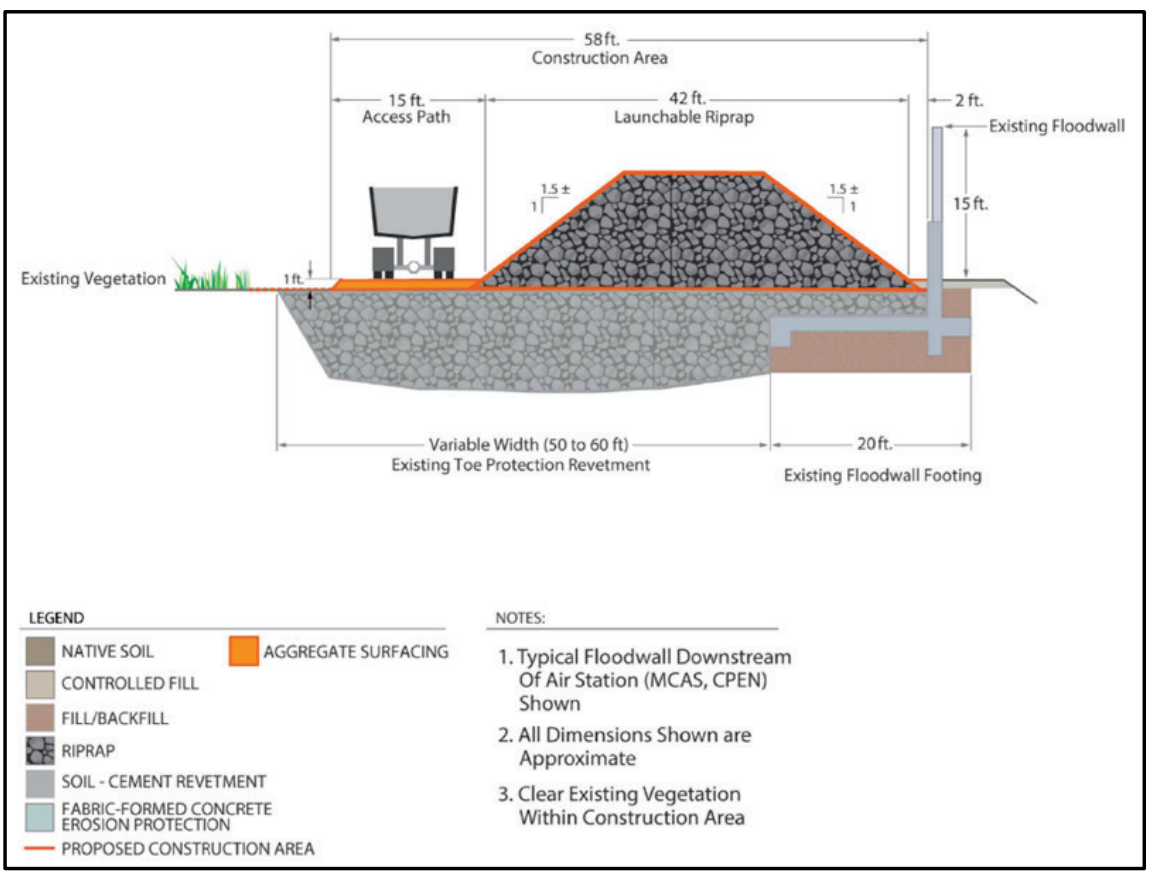




\section{Inspection Findings and Conclusions}

\subsection{Key inspection findings and recommendations}

The ERDC supplemental levee inspection identifies the primary deficiency as both weedy and woody vegetation encroaching on the levee right-of-way and on its pertinent features. A list of inspection findings is summarized below, along with recommendations regarding their remediation:

1. Extensive weedy and woody vegetation are located within the vegetation-free zone. A vegetation-free zone should be maintained such that observations can easily be made during flood stages. These types of observations provide project personnel the opportunity to identify potential flaws in the levee embankment in a timely manner and perform needed remediation to the levee.

2. Depressions were observed in the riverside riprap revetment throughout the levee system. These depressions could be due to scour of poorly placed and graded riprap, cover material, and/or rock settlement. The depressions should be further inspected following vegetation removal and regraded or replaced with more suitable material.

3. Cracks observed on the levee crest and slopes should be sealed to prevent further degradation of the levee. Monitoring should be continued and, if further movement is identified, an engineering assessment should be made followed by remediation that is deemed appropriate.

4. Weathering of the levee embankment, although not a primary deficiency currently, should be monitored for progression. A method of sealing or protecting the riverside levee slope should be considered to prevent more costly future repairs.

5. A pest control program should be implemented, as animal burrow activity is a fairly common occurrence, especially along the landside of the floodwall.

6. The standing water noted on the riverside toe of the levee upstream and downstream of the pump station should be investigated. A method of regrading the drainage channel such that the standing water drains properly should be devised. 
7. Results of the document review did not identify a formal emergency action plan. An emergency action plan (EAP) should be developed that contains or incorporates the following items:

- An appropriate named individual to act as a levee safety officer (LSO). This individual would be responsible for the EAP, developing levee operations, and ensuring activities are performed that are described in the maintenance manual. Additionally, the LSO would provide expertise and lead any flood-fighting efforts.

- Ensure that multiple employees are trained and physically capable of performing annual inspections, including reports of the levee system and coordination of flood-fight operations (e.g., hourly to daily inspections depending on river stages, bagging of potential sand boils, and observing scour). During adverse weather conditions is an especially important time to identify problematic conditions and to target flood-fight personnel and resources, directing them to trouble spots should they occur. This type of vigilance is especially important in the event that evacuation warnings become necessary.

- Ensure the river gauge on the Basilone Road Bridge is functioning by performing periodic checks so river stages can be accurately established during flood monitoring. An operational gauge is an important part of the EAP for increasing the frequency of observation during flood loadings of the levee.

- Ensure the roadway on the levee crest is free of any vegetation and capable of vehicle passage for flood monitoring and flood fighting at problem locations.

8. The operations and maintenance (O\&M) manual should be updated to reflect the current status of the levee system, to include all remedial efforts that have been conducted since the construction of the levee system. The current manual has not been updated since construction of the levee.

\subsection{Conclusions}

Based on review of the proposed remediation of the levees at MCAS Camp Pendleton, it appears that due diligence by the designers was followed. Of the alternatives considered, those deemed most appropriate provide a minimal impact to the surrounding environment and address those deficiencies identified in previous levee inspections. 
The major deficiency identified previously was that of vegetation encroachment into the vegetation-free zone. A likely reason for the encroachment on the riverside levee right-of-way was poor access. Enhanced access to the riverside of the levee will allow for regular maintenance and inspections. Additionally, the access path will force regrading of the riverside toe in the west levee segment, which will allow for the drainage of the observed standing water at the riverside toe of the levee.

Two additional discrepancies were identified in the inspection performed by ERDC personnel: the failure to update the original O\&M since completion of the levee and the lack of a formalized EAP.

It may be appropriate to have the O\&M manual updated following the completion of the proposed remediation. The EAP is a formal document (USACE 2018) that identifies potential emergency conditions at a project and specifies pre-planned actions to be followed during flood events to reduce the consequences of the emergency.

Central to the EAP is the automated river staff gauge station at Basilone Bridge to provide trigger points for daily and hourly monitoring, as well as implementation of a flood-fight program should it become necessary. 


\section{References}

BergerABAM. 2018a. Draft levee remedial alternatives and cost estimating report, Marine Corps air station, Camp Pendleton, California. Contract Number N62473-14-D-0062/o022, Shannon and Wilson Report PA1803M Repair Levee. Washington, DC: BergerABAM.

. 2018b. Existing documentation review, Marine Corps air station, Camp Pendleton, California. Contract Number N62473-14-D-0062/0022, Shannon and Wilson Report PA1803M Repair Levee. Washington, DC: BergerABAM.

. 2018c. Geotechnical data report, Marine Corps air station, Camp Pendleton, California. Contract Number N62473-14-D-0062/o022, Shannon and Wilson Report PA1803M Repair Levee. Washington, DC: BergerABAM.

.2018d. Levee evaluation technical memorandum, Marine Corps air station, Camp Pendleton, California. Contract Number N62473-14-D-0062/o022, Shannon and Wilson Report PA1803M Repair Levee. Washington, DC: BergerABAM.

. 2018e. Santa Margarita River hydraulic evaluation, Marine Corps air station, Camp Pendleton, California. Contract Number N62473-14-D0062/o022. Shannon and Wilson Report by WEST Consultants Inc. as subcontractor, PA 1803M Repair Levees. Washington, DC: BergerABAM.

. 2018f. Site characterization technical memorandum, Marine Corps air station, Camp Pendleton, California. Contract Number N62473-14-D0062/0023, Shannon and Wilson Report PA1803M Repair Levee. Washington, DC: BergerABAM.

2019a. Concept design submittal basis of design, levee repair Marine Corps Air Station (MCAS), Camp Pendleton, California. Washington, DC: Berger ABAM.

. 2019b. Cost estimate, levee repair MCAS Camp Pendleton, California. eProject No. 1578564, Contract No. N6247314Doo62, Task Order No. N6247317F4730. Washington, DC: Berger ABAM.

. 2019c. Levee remedial alternatives and cost estimating report, Marine Corps Air Station, Camp Pendleton, California, Contract Number N62473-14-Doo62/oo22. Shannon and Wilson Report PA1803M Repair Levee. Washington, DC: Berger ABAM.

. 2019d. Levee repair MCAS Camp Pendleton, California. eProject No. 1578564, Contract No. 6247314Doo62, Task Order No. N6247317F4730. Washington, DC: Berger ABAM.

Terracon and GEI (Terracon Consultants and GEI Consultants). 2012. Levee and floodwall safety inspections Marine Corps base Camp Pendleton. Prepared by GEI Consultants Inc. for Terracon Consultants. Irvine, CA: GEI Consultants Inc. 
U.S. Army Corps of Engineers (USACE). 2005. Design guidance for levee underseepage. ETL-1110-2-569. Washington, DC: USACE.

. 2014. Guidelines for landscape planting and vegetation management at levees, floodwalls, embankment cams and appurtenant structures. ETL-1110-2583. Washington, DC: USACE.

. 2017. Levee safety inspection report, Santa Margarita River Levee. Prepared by Schnabel Engineering LLC, Alpharetta, GA., for Norfolk District Army Corps of Engineers. Alpharetta, GA: Schnabel Engineering. 2018. Guidance for emergency action plans, incident management and reporting. EC-1110-2-6074. Washington, DC: USACE.

. 2020. Levee inspection. https://www.usace.army.mil/Missions/CivilWorks/Levee-Safety-Program/Levee-Inspections/

Winzler and Kelly Consulting Engineers. 2001. Operations and maintenance manual Santa Margarita River flood control levee. Construction Contract No. N6871197-C-8338, MCON P-010, Santa Margarita River Flood Control Project. Santa Rosa, CA: Winzler and Kelly. 


\section{Unit Conversion Factors}

\begin{tabular}{|l|c|l|}
\hline Multiply & By & To Obtain \\
\hline feet & 0.3048 & meters \\
\hline hectares & $1.0 \mathrm{E}+04$ & square meters \\
\hline inches & 0.0254 & meters \\
\hline miles (U.S. statute) & $1,609.347$ & meters \\
\hline
\end{tabular}




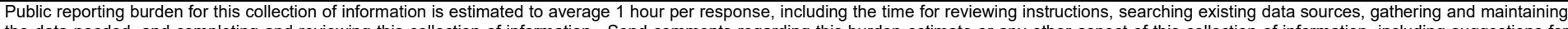

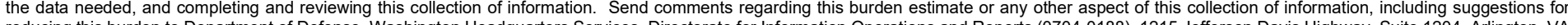

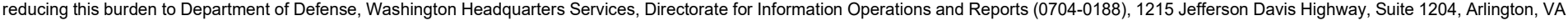

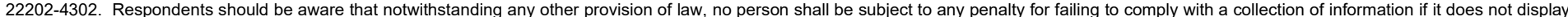
a currently valid OMB control number. PLEASE DO NOT RETURN YOUR FORM TO THE ABOVE ADDRESS.

\begin{tabular}{l|l|l} 
1. REPORT DATE (DD-MM-YYYY) & 2. REPORT TYPE & 3. DATES COVERED (FrOm - TO)
\end{tabular} August 2021 Final

\section{TITLE AND SUBTITLE}

Geotechnical Inspection and Technical Review of Santa Margarita River Marine Corps

Air Station Levee, U.S. Marine Corps, Camp Pendleton, CA, 19-20 November 2019

5a. CONTRACT NUMBER

5b. GRANT NUMBER

5c. PROGRAM ELEMENT NUMBER

\section{AUTHOR(S)}

Lucas A. Walshire and Joseph B. Dunbar

5d. PROJECT NUMBER

5e. TASK NUMBER

5f. WORK UNIT NUMBER

7. PERFORMING ORGANIZATION NAME(S) AND ADDRESS(ES)

8. PERFORMING ORGANIZATION REPORT NUMBER

Geotechnical and Structures Laboratory

U.S. Army Engineer Research and Development Center

ERDC/GSL SR-21-3

3909 Halls Ferry Road

Vicksburg, MS 39180-6199

9. SPONSORING / MONITORING AGENCY NAME(S) AND ADDRESS(ES)

10. SPONSOR/MONITOR'S ACRONYM(S)

Marine Corps Air Station

Camp Pendleton, CA 92055

11. SPONSOR/MONITOR'S REPORT NUMBER(S)

\section{DISTRIBUTION / AVAILABILITY STATEMENT}

Approved for public release; distribution is unlimited.

\section{SUPPLEMENTARY NOTES}

Project DD1144-2019-GSL-604 for an Independent Technical Review of the Proposed Santa Margarita Levee Rehabilitation Project, Camp Pendleton, CA, MIPR M0220821MPFE001.

\section{ABSTRACT}

This report describes activities performed, results obtained, and conclusions made from an independent technical review of past levee inspections and the proposed remediation plan for the Santa Margarita Levee that surrounds the U.S. Marine Corps Air Station (MCAS) Camp Pendleton. In support of the technical review, ERDC personnel performed a supplemental levee inspection on 19 and 20 November 2019 with MCAS personnel. Previous levee inspections had rated the levee system as Unacceptable due to unwanted vegetation encroaching on the levee right-of-way, which prevents full inspection during flooding. Concerns were raised by the U.S. Fish and Wildlife (USFW) about environmental impacts of the proposed remediation measures and the necessity of such actions.

USFW personnel requested an engineering review from an independent party, and ERDC was tasked with performing the independent technical review. The following special report describes the tasks performed and results obtained from the independent technical review.

\begin{tabular}{lll}
\hline 15. SUBJECT TERMS & Levee rehabilitation & Levees-Inspection \\
Levee inspection & Soil cement levee & Flood control
\end{tabular}

Camp Pendleton levee

16. SECURITY CLASSIFICATION OF:

Camp Pendleton (Calif.)

\begin{tabular}{|l|l|}
\hline a. REPORT & b. ABSTRACT \\
Unclassified & Unclassified
\end{tabular}

17. LIMITATION OF ABSTRACT

c. THIS PAGE
Unclassified
18. NUMBER OF PAGES

SAR
43 19a. NAME OF RESPONSIBLE PERSON

19b. TELEPHONE NUMBER (include area code) 